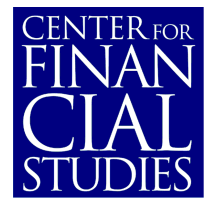

No. $2001 / 01$

\title{
Underpricing of Venture-Backed and Non Venture-Backed IPOs: Germany's Neuer Markt
}

Stefanie A. Franzke

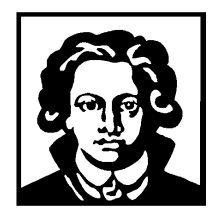


No. $2001 / 01$

Underpricing of Venture-Backed and Non Venture-Backed IPOs:

Germany's Neuer Markt

Stefanie A. Franzke 
CFS Working Paper No. 2001/01

\title{
Underpricing of Venture-Backed and Non Venture-Backed IPOs: Germany's Neuer Markt
}

\author{
Stefanie A. Franzke* \\ First Version: February 26, 2001 \\ This Version: September 22, 2001
}

\begin{abstract}
This paper analyzes a comprehensive data set of 108 non venture-backed, 58 venture-backed and 33 bridge financed companies going public at Germany's Neuer Markt between March 1997 and March 2000. I examine whether these three types of issues differ with regard to issuer characteristics, balance sheet data or offering characteristics.

Moreover, this empirical study contributes to the underpricing literature by focusing on the complementary or rather competing role of venture capitalists and underwriters in certifying the quality of a company when going public. Companies backed by a prestigious venture capitalist and/or underwritten by a top bank are expected to show less underpricing at the initial public offering (IPO) due to a reduced ex-ante uncertainty. This study provides evidence to the contrary: VC-backed IPOs appear to be more underpriced than non VCbacked IPOs.
\end{abstract}

Keywords: Venture Capital, Underwriter, Initial Public Offering, Underpricing, Neuer Markt JEL classification: G32

\footnotetext{
* Center for Financial Studies at the Johann Wolfgang Goethe-Universität, Taunusanlage 6, D-60329 Frankfurt/Main, Germany. Phone: +49-69-24 2941 16, Fax: +49-69-24 2941 77, Email: franzke@ifkcfs.de.
}

To be presented at the Annual Meeting of the Verein für Socialpolitik in Magdeburg and the 8th Annual Meeting of the German Finance Association in Vienna. 


\section{Introduction}

Venture capitalists are described as experts in the field of high-risk company funding (see for example Fenn/Liang/Prowse (1997), SAhLMAN (1990) and LerNer (1995)). They not only specialize by concentrating on certain industry sectors and specific stages of a company's development, but also actively engage in monitoring and consulting activities. Since they often serve as members on the "Aufsichtsrat" and frequently invest their capital based on whether intermediate goals have been reached, they are able to influence the behavior and corporate strategy of the company under consideration. The ir incentive to improve corporate governance is on the one hand due to the finite life of the partnership and - since their compensation is linked to the firm's performance - to the maximization of the exit price. ${ }^{2} \mathrm{On}$ the other hand, being repeat players who regularly have to raise new funds, venture capitalists face reputational risk. One would therefore expect that, much like prestigious underwriters or auditors, venture capitalists certify the quality of a company when going public.

Within the extensive underpricing literature some empirical studies examine whether the market honors the presumed monitoring-activities of venture capitalists. Since this control benefit may reduce the ex-ante uncertainty for future investors, it should lead to lower underpricing. Underpricing is defined as the spread between the initial offering price and the opening price on the first day of trading. However, empirical evidence is mixed. Among others, BARry/Muscarella/PEAvy/VETSUYPENS (1990) and MEgGinson/WeISS (1991) confirm the certification role of venture capitalists for the US market. They find evidence for venture capital (VC)-backed IPOs suffering less underpricing than non VC-backed IPOs. On the other hand, FRANCIS/HASAN (2001) and SMART/ZUTTER (2000), who also analyze US data, find initial returns of venture-backed IPOs on average to be higher than those of non venture-backed IPOs.

LJUNGQVIST (1999) using the data set of MEGGINSON/ WEISS (1991), demonstrates that the finding of venture-backed IPOs appearing less underpriced has to be attributed to the incentives of the old shareholders to reduce underpricing and not to the circumstance of venture-backing. Old shareholders will care for the pricing of an issue or for the choice of an

\footnotetext{
1 The „Aufsichtsrat“" is similar to the supervisory board. However, German stock companies are governed by two boards. The supervisory board on the one hand is elected by and represents shareholders. Moreover, it appoints the company's executive board. The executive board on the other hand comprises firm managers and oversees day-to-day operations.

${ }^{2}$ When selling at the time of the initial public offering (IPO), this price is equivalent to the offer price.
} 
underwriter to the extent that such decisions affect their wealth. LJUNGQVIST illustrates, that underpricing-induced wealth losses increase with the number of shares sold in the IPO. As a consequence companies selling a lot of old shares should show little underpricing, due to the incentives of the old shareholders to reduce underpricing.

This study contributes to the underpricing discussion. It analyzes the certification role of venture capitalists and underwriting banks ${ }^{3}$ at the IPO exploring a unique German data set of companies going public at Neuer Markt. Moreover it considers the argumentation offered by LJUNGQVIST (1999) and examines the incentives of the old shareholders to take influence on underpricing using similar variables and applying ordinary least square regression calculations. The analysis of the German market is of particular interest since it sheds more light on the importance of venture capital in a bank-based financial system. In Germany VC financing has only recently taken off as an important part of the financial services industry. As a consequence only little empirical work is available to date. Few information exist for instance about the players on the German VC market, their investments and divestment activities. Thus, this paper has two objectives, first, to enlarge the level of knowledge with respect to venture capital financing in Germany focusing on underpricing and second to compare the results found with those of international studies.

The main result of this study with respect to underpricing is, that venture-backed IPOs at Neuer Markt experience considerably more underpricing than non-venture backed IPOs. This phenomenon can not be explained following arguments in the literature.

The paper is organized as follows: Section II summarizes the history of venture capital in Germany and its driving factors. Section III outlines the impact of the introduction of the Neuer Markt at Frankfurt Stock Exchange on the primary equity market in Germany. Moreover, it provides an analysis of the IPO-costs for Neuer Markt issues. In section IV based on the theoretical literature on underpricing and certification mechanisms - the testable hypotheses are formulated. Section V describes the data set and the design of the empirical analysis. In sections VI and VII descriptive statistics and the empirical results are presented. The paper concludes with a summary and an outlook in section VIII.

\footnotetext{
3 Due to the narrow underwriting market until 1998, only two empirical studies exist analyzing the certification role of underwriters in Germany (see W ASSERFALLEN/WITTLEDER (1994) and KASERER/KEMPF (1995)).
} 


\section{Venture Capital Financing in Germany}

The definition of "venture capital" differs in the literature ${ }^{4}$. In the Anglo-American understanding "venture capital" is often used in the context of early-stage (such as seed and start-up financing) and expansion financing. In Germany, "venture capital" is more comprehensive, since it also includes later-stage capital (such as bridge-, buy out-, and turnaround-financing). ${ }^{5}$ While the former types of investments are crucial for the development and implementation of business ideas by young growth companies, the latter types of investments are important for capital structure reasons of more mature, small to medium-sized companies. To be aware of venture capital's different meanings is important when interpreting (German) figures and in particular when comparing empirical results of various international studies.

VC financing in Germany has been insignificant and underdeveloped until recently. ${ }^{6}$ The literature analyzing the manifold reasons, discusses in particular the social environment (e.g., status of entrepreneurs, the relationship of academia and trade and industry), legal and tax regulations and the exit conditions for venture capitalists (see e.g. LEOPOLD/FROMMANN (1998), BECKER/HELLMANN (2000) and BETSCH/GROH/SCHMIDT (2000)).

Searching for the roots of the current German venture capital industry one has to go back to the year 1965, when the first "Kapitalbeteiligungsgesellschaften" (KBGs) were founded, most of them by banks. ${ }^{7}$ The success of KBGs was modest, the number of investments, primarily in established medium-sized companies was small. ${ }^{8}$

With the launch of the European Recovery Program (ERP-Program) initiated by the German government in 1971 the investment focus was extended to small- to medium sized companies and setting-up of businesses. The program's goal was (and still is) to refinance such investments at a preferential interest rate and to insure venture capitalist against potential

\footnotetext{
4 For a deeper discussion see e.g. BYGRAVE/TimMONS (1992), STEDLER (1986), BETSCH/GROH/SCHMIDT (2000) and BALZER (2000).

${ }^{5}$ This broader expression is comparable to the American understanding of private equity.

${ }^{6}$ The historical overview presented here follows the description of LESSAT ET AL. (1999).

7 To compare, in England going back to the initiative of the Bank of England and with the cooperation of major banks the Industrial and Commercial Finance Corporation Ltd. (ICFC), today known as 3i was established in 1945. On the other hand in the United States the first professional venture capital company named "American Research and Development Corporation" (ARD) was founded in 1949.

${ }^{8}$ According to LEOPOLD/FrOMMANN (1998) 33 KBGs have been founded between 1965 and 1972. Even though 20 of these do still exist, only 2 have some importance within the VC-industry today.
} 
losses. ${ }^{9}$ Since the existing KBGs made only little use of this form of refinancing, the German states started to support the establishment of so-called "Mittelständische Beteiligungsgesellschaften" (MBGs). Primarily MBGs had the task to improve the equity base of local companies by investing the financial means offered by the governmental ERP-program. Even though publicly subsidized equity for investment purposes became relatively more important, the major part (amounting to $70 \%$ of the total volume) was still provided by banks. Overall, the venture capital market experienced only little development. The level of the invested volume was rather low, amounting to approximately $€ 0,29$ billion by the end of 1979 .

Finally, in 1983 the German VC industry started to expand. German equity investment companies, copying the sucessful setup of American venture capitalists were founded. MBGs, which had to experience little deal flow during the seventies, became reactivated. Banks and industrial companies expanded their involvement, e.g., by founding affiliated VC companies.

With the beginning of the nineties, the time of the German reunification, the importance of early-stage financing became more of an issue. The number of newly established businesses ${ }^{10}$ increased. Venture capitalists started to specialize. Moreover the government extended its program, making financial support available especially to start-up and early-stage investments ${ }^{11}$. VC became a truly attractive proposition for investors in the German economy. Until 1996, a continuous, almost linear growth of the VC industry could be observed, followed by a period of exponential growth. ${ }^{12,13}$

This recent development can mainly be attributed to the increasing liquidity of investors, the foundation of new VC companies, the rising public interest and in addition, following HEILMANN (2000), to the considerable number of foreign venture capitalists entering the German market.

\footnotetext{
9 Such programs are carried out by the "Kreditanstalt für Wiederaufbau" and the "Deutsche Ausgleichsbank". The internet page of the FEDERAL MINISTRY OF ECONOMICS AND TECHNOLOGY offers further information: http://www.bmwi.de/

${ }^{10}$ In the appendix figure A.1 presents estimations of the INSTITUT FÜR MITTELSTANDSFORSCHUNG (IFM) about business foundations since 1975 in Germany.

${ }^{11}$ To be mentioned are programs of the "Deutsche Ausgleichsbank" and the "Kreditanstalt für Wiederaufbau", such as the „Beteiligungskapital fur junge Technologieunternehmen“ (BJTU) or the „Beteiligungsprogramm für kleine Technologieunternehmen“(BTU), respectively.

${ }^{12}$ See Figure 1 on page 5. Figures containing data of the members of the BVK account to (according to BVK) $90 \%$ of the volume of the German VC market.

${ }^{13}$ For the development of gross investments of members of the BVK (in $€$ Mio.) and the number of beneficiary companies see figure A.2. in the appendix.
} 
Figure 1: Total Portfolio Held by Members of the Bundesverband Deutscher

Kapitalbeteiligungsgesellschaften e.V. (BVK) (in € Billion)

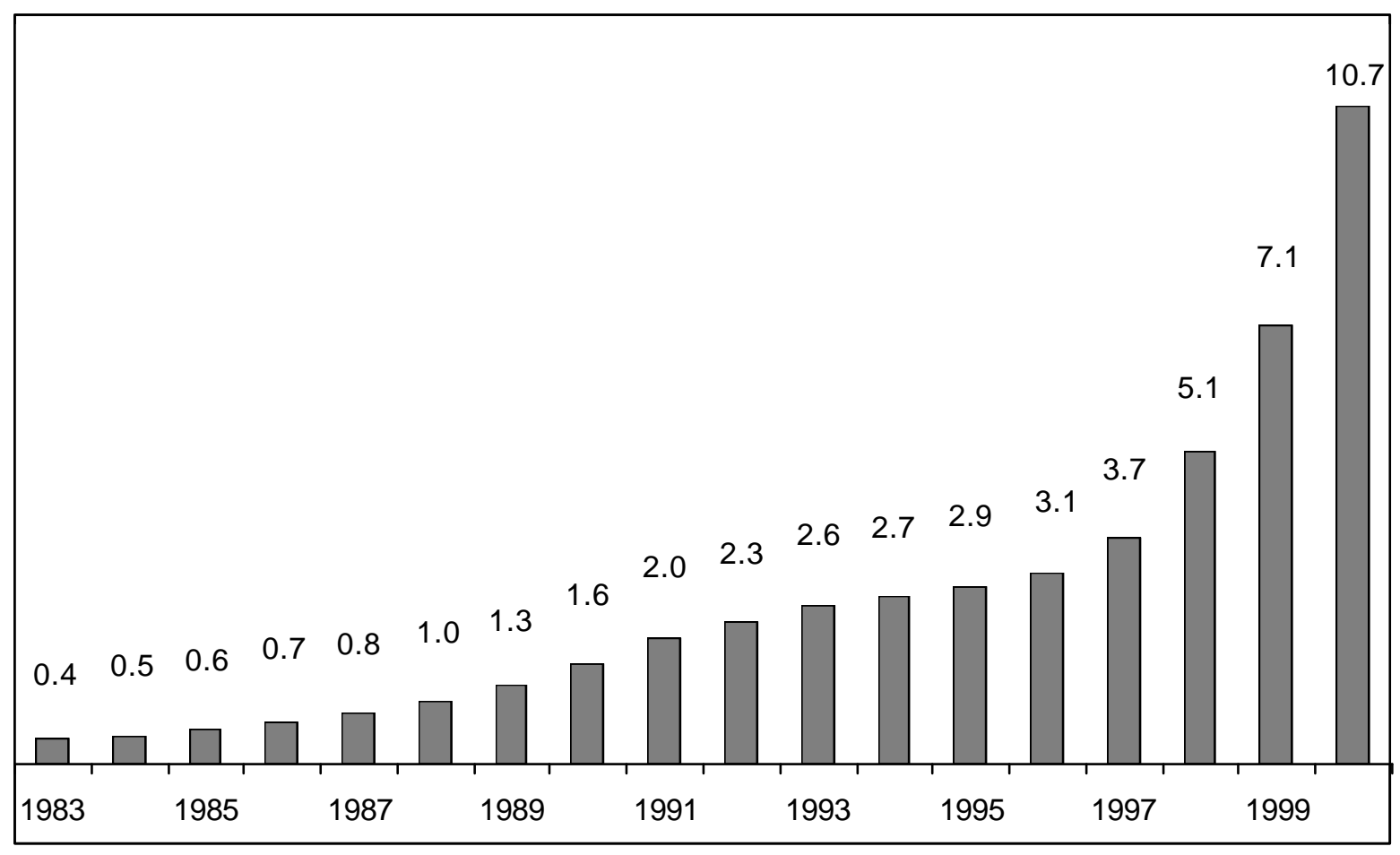

The increase would have been impossible without a fundamental change in Germany's funding and investment environment. Accompanied by regulatory changes ${ }^{14}$ and an upswing in the German equity culture ${ }^{15}$, the launch of the Neuer Markt in March 1997, offering a further exit mechanism for venture capitalists, has to be seen as most stimulating for the German venture capital industry. ${ }^{16}$ Compared to other strategies, exiting a VC investment by the means of an IPO is attractive as it usually results in the highest valuation of a company. ${ }^{17}$ Furthermore, the potential exit through an IPO permits the entrepreneur and venture capitalist to enter into an implicit contract concerning the future corporate control. ${ }^{18}$

\footnotetext{
${ }^{14}$ Amendment of the "Gesetz für Unternehmensbeteiligungsgesellschaften" (UBGG) within the changes of the 3rd ,Finanzmarktförderungsgesetz“.

15 According to the magazine DIE BANK (2000), Germany is more and more establishing an equity culture. Evidence is given by an annual opinion survey: Of the persons asked, the percentage of investors in stocks (equity funds) has risen from 13\% (9\%) in 1996 to 22\% (28\%) in 1999. Moreover the DAI-FACTBOOK (2000) of the "Deutsches Aktieninstitut" (DAI) shows that stocks constitute about $13 \%(8 \%)$ of the financial assets of private households in 2000 (1996).

16 According to BECKER/HELLMANN (2000), the launch of the "Geregelter Markt" in 1987 had almost no effect on the venture capital industry.

${ }^{17}$ See for example SMITH/SMITH (2000). For an empirical analysis on the efficient pattern on exit vehicles see CUMMING/MACINTOSH (2001)

${ }^{18}$ For a detailed discussion see e.g. JENG/WELLS (1998) and BLACK/GILSON (1998).
} 
Table 1 describes volume and percentage of various exit vehicles. The table shows a relation between the introduction of the Neuer Markt and the increasing importance of IPOs for venture capitalists in Germany since 1998.

Table 1: Volume and Percentage of Exit Vehicle as stated by BVK

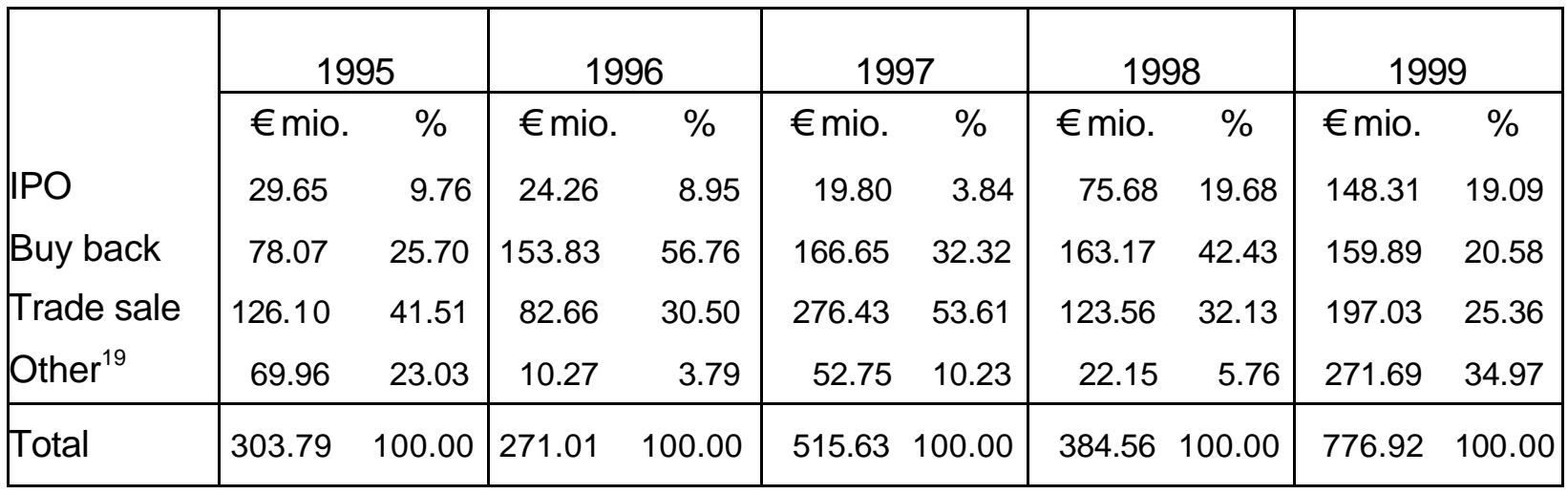

Therefore, a closer examination of this market segment seems worthwhile, as it covers on average about $53 \%$ of public offerings backed by venture capital since $1998 .^{20}$

\section{Germany's Neuer Markt and the Costs of Raising Capital}

The Neuer Markt is Germany's trading segment for innovative growth companies. It was launched in March 1997 as a subsidiary of the Deutsche Börse AG, with the objective to attract small- to medium-sized, young technology firms. As figure 2 indicates, the number of companies that have gone public in Germany or rather on the New Market has increased dramatically, since 1997. From March 1997 through March 2000, over 200 companies went public on the Neuer Markt, while at the same time new listings at the first and second segment stayed close to their previous levels. In total about 320 new listings were recorded for that period. $^{21}$

\footnotetext{
${ }^{19}$ The classification "Other" in 1999 contains, among other things, selling to a financial investor or divestment through write-off (see BVK yearbook 2000).

${ }^{20}$ The remaining 47\% can be split into IPOs on other German stock markets (20\%) and listings on foreign stock exchanges (27\%) such as the NASDAQ.

Beyond that there is evidence for the international acceptance of this market as it is more and more chosen as exit mechanism by foreign venture capital funds $(7 \mathrm{O} / 3 \mathrm{CH} / 3 \mathrm{USA}-\mathrm{C} / 2 \mathrm{Isr} / 2 \mathrm{UK}$ during the period March 1997 to March 2000).

${ }^{21}$ According to JOHNSON (2000), from 1949 through 1996 a total of only 356 companies went public in Germany.
} 
Figure 2: New Issues in Germany ${ }^{22}$ (in Numbers)

during the Period March 10, 1997 to March 10, 2000

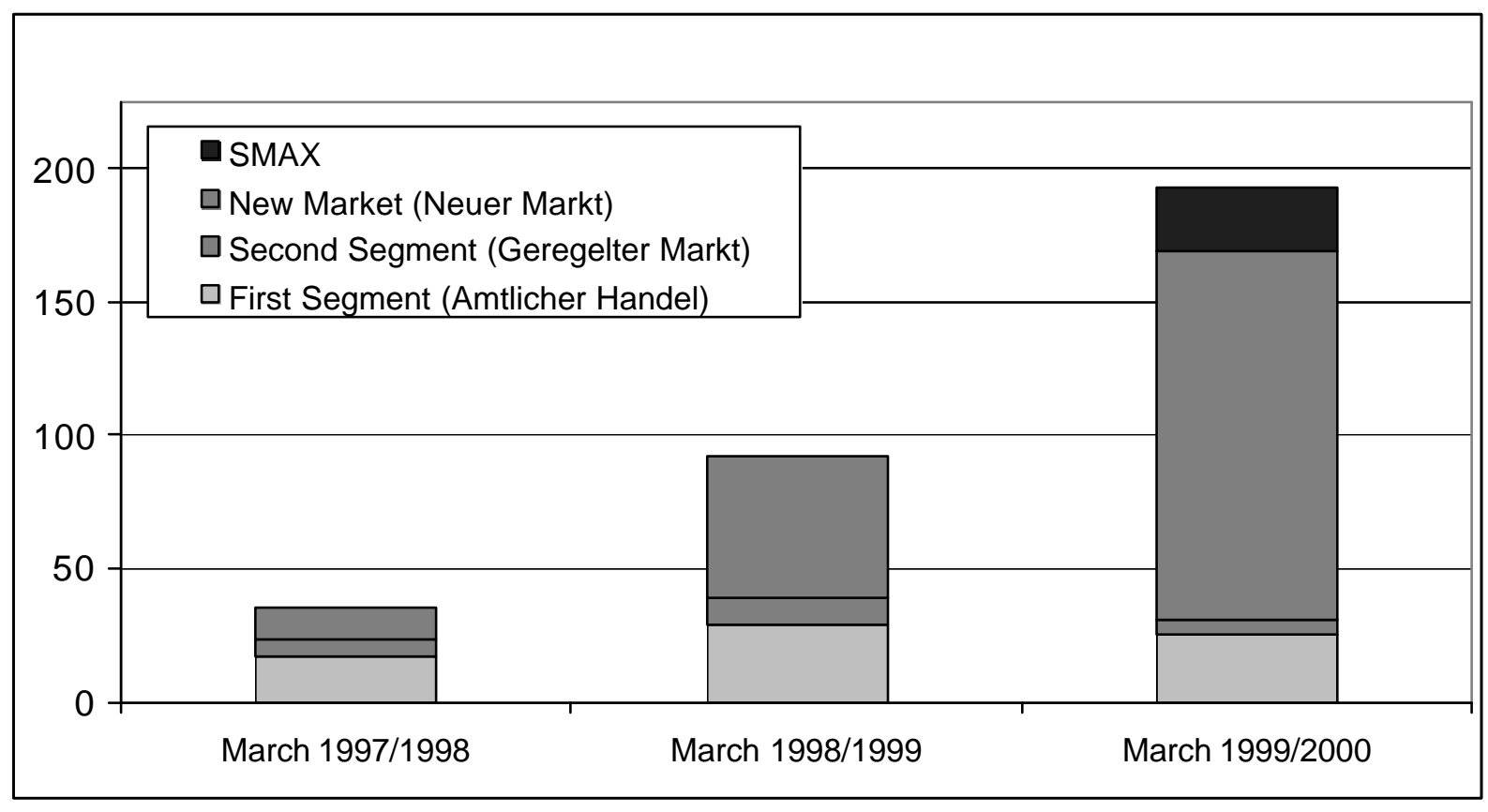

In order to provide investors with information about the quality of these IPO candidates, the Neuer Markt set up much stricter listing and disclosure requirements than the established exchanges. JOHNSON (2000) describes and compares the standards in Germany (all markets of the Frankfurt Stock Exchange) and the United States (NYSE, NASDAQ) in detail. ${ }^{23}$ He states that more rigid rules of disclosure on the Neuer Markt have an effect both on the number and on the nature of companies that go public. $^{24}$

What is remarkable about the "how to go public" at the Neuer Markt is that from March 1997 to March 2000 all but one company (TRIUS AG) ${ }^{25}$ chose book-building to price the shares. ${ }^{26}$

${ }^{22}$ On the SMAX (Small Cap Exchange) - introduced in April 1999 - second market stocks are traded. The listing requirements of the SMAX follow - apart from small modifications - those of the Neuer Markt.

${ }^{23}$ For an assessment, whether the high listing and information demands of the Neuer Markt lead to the desired increased transparency and improved liquidity, thus providing confidence to investors, see e.g. LEUZ (2000), GERKE/BOSCH (2000) and THEISSEN (1998).

${ }^{24} \mathrm{He}$ underpins his view by the significant increase in IPOs and the high number of small, young companies that went public at Neuer Markt. However, more rigid disclosure rules might be one reason for the increase of IPOs, but other explanations are manifold. Just to mention some: The IT-revolution, the high number of newly founded comp anies since the German reunification, the simultaneous decline of margins at the bank lending business and the growing popularity of investment banking.

25 Trius AG went public by using a tender procedure, selling the stocks via an auction.

${ }^{26}$ Until 1995 it was common to use the fixed-price method in Germany. One of the main imperfections of this method in comparison to book-building is, that underwriting banks have a vital interest to set up a low offer price: Since they do not receive any information concerning demand (e.g. through bids by institutional and retail investors) before the price fixing, they have more to care for the placement risk. 
Although during the observation period two out of three issues were oversubscribed ${ }^{27}$, the final issue price was always fixed within the book-building range ${ }^{28}$ and never above; merely twice $^{29}$ it remained under the minimum price limit. Following LJUNGQVIST/JENKINSON (2000), the reluctance to price outside the range is distinct in Germany compared to international practice. The major potential benefit of book-building, to raise the price, if demand is unexpectedly high, seems hardly be exhausted. ${ }^{30}$ This is worth mentioning as the pricing has influence on the costs of going public.

In order to analyze the issuing costs for companies at Neuer Markt in more detail, one can distinguish between direct and indirect costs, as listed in table $2 .^{31}$

The direct costs contain for example auditing and consulting fees, underwriting fees, marketing costs, or fees raised by the Frankfurt Stock Exchange for the admission to the first segment, for the filing of the prospectus and for services provided by Deutsche Börse AG. ${ }^{32}$ The numbers quoted here are calculated from information indicated in the issuing prospectuses of the companies under consideration. During the period of March 1997 through March 2000, companies going public on the Neuer Markt had to bear on average total direct flotation costs of $8.43 \%$ of gross proceeds. As part of these costs the average underwriting fee amounted to $5.14 \%$ of gross proceeds, respectively.

The indirect costs in the form of underpricing ${ }^{33}$ average $63.37 \%$. In other words, the average issuing company could have raised about $€ 29$ million more, if the first market price would have been in correspondence with the offering price.

\footnotetext{
27 This is in the interest of the management as an oversubscription of the offering enables the management to take more influence on the allotment (see among others BRENNAN/FRANKS (1997)).

$2880,4 \%$ of the IPOs of the sample have been fixed exactly at the upper price limit.

29 These companies have been MSH International Services AG (book-building range/issuing price: $€$ 18.50$21.50 / € 15.50)$ and Euromed AG (€ 10.50-13.50 / € 9.00).

${ }^{30}$ LJUNGQVIST/JENKINSON (2000) merely conject that local regulations, the costs caused by price revisions or the market power of domestic investors could serve as explanations for the unwillingness to raise the price.

${ }^{31}$ For a cross-sectional analysis of the costs of raising capital in Germany, see: KASERER/KRAFT (2000).

${ }^{32}$ Strictly speaking the value of the greenshoe-option has to be added to these costs. To stabilize the stock price following the IPO, the issuer grants the underwriter the option to sell additional shares at the issue price and trade them for a time period of thirty days, if necessary. According to OCHNER (2000), underwriters do almost constantly retain the earnings gained by selling additional shares at the issue price (or eventually a higher secondary market price) and purchase them back as soon as the price of the shares falls below the issue price. This "gift" of the issuer to the underwriter can be explained by the high number of issues, which shifts the bargaining power to the underwriter.

${ }^{33}$ Underpricing is equivalent to a positive initial return, as the first market price exceeds the offer price.
} 
Table 2: Costs of Going Public at the Neuer Markt (March 1997 - March 2000)

"Money left on the table" is calculated by multiplying the total volume of issues with the initial return or rather the underpricing, which is the spread between the opening price at the first day of trading and the initial offering price. Dividing the direct flotation costs by the gross proceeds of an issue, one receives the relative direct costs. The relative underwriting fee is defined as the underwriting fee paio at IPO normalized by the gross proceeds of the issue.

\begin{tabular}{|l|c|c|c|c|c|c|}
\hline \begin{tabular}{l} 
In $\begin{array}{l}\text { } \\
\text { respectively } \%\end{array}$ \\
\hline Direct flotation costs
\end{tabular} & 3,447 & 2,683 & 2,525 & 613 & 14,640 & 191 \\
\hline Underwriting fees & 2,252 & 1,800 & 1,818 & 225 & 11,600 & 187 \\
\hline $\begin{array}{l}\text { Indirect costs: Money } \\
\text { left on the table }\end{array}$ & 28,991 & 9,180 & 47,415 & $-10,800$ & 336,375 & 199 \\
\hline Gross issue proceeds & 48,767 & 36,500 & 42,836 & 8,278 & 283,650 & 199 \\
\hline Relative direct costs & $8.43 \%$ & $7.86 \%$ & $3.03 \%$ & $4,43 \%$ & $26.85 \%$ & 191 \\
\hline $\begin{array}{l}\text { Relative underwriting } \\
\text { fees }\end{array}$ & $5.14 \%$ & $5.13 \%$ & $1.34 \%$ & $0.87 \%$ & $13.04 \%$ & 187 \\
\hline Initial return & $63.37 \%$ & $30.43 \%$ & $82.18 \%$ & $-14.50 \%$ & $433.33 \%$ & $199^{35}$ \\
\hline
\end{tabular}

Compared to the degree of underpricing on the German IPO market earlier studies ${ }^{36}$ report, the extent of underpricing at the Neuer Markt seems to be remarkably high. This might be in line with the finding of STEHLE/ERHARDT (1999), that small, relatively unknown companies have high initial returns.

\section{Related Literature and Hypotheses}

The theoretical literature on underpricing (for an extensive overview, see JENKINSON LJUNGQVIST (1998)) can be divided into two main categories.

There is theoretical work, which focuses on asymmetric information within the group of investors, between issuer and underwriter and between issuer and investors. Secondly, there are institutional explanations that try to attribute the existence of underpricing to factors such

\footnotetext{
${ }^{34}$ These are the observations of the sample used for the analysis in section five. The number of observation is varying, since some issuing prospects offered only aggregated information.

3513 of the 199 observations are overpriced as indicated by the negative initial return. 17 observations have an initial return of $0.00 \%$.

36 See for example ERHARDT (1997), LJUNGQVIST (1997), KASERER/KEMPF (1995) or WASSERFALLEN WITTLEDER (1994). A recent study by LÖFFLER (2000) on the Neuer Markt offers comparable numbers.
} 
as price support by the underwriting bank, liability regarding the statements made in the issuing prospectus or aspects of corporate ownership and control.

This paper focuses on theories based on asymmetric information between issuer and investors. Within this branch different methods are discussed in order to reduce this "market imperfection". Signaling models e.g. by ALLEN/FAULHABER (1989), GRINBLATT/HwANG (1989) or WELCH (1989) suggest that from the level of underpricing investors can draw conclusions about the quality of the issuing companies. ${ }^{37}$ CARTER/MANASTER (1990) and BоOTH/SMiтH (1986) however emphasize the signaling and certification-of-quality role fulfilled by prestigious underwriters, the like goes for auditors and venture capitalists. In the following I will concentrate on the latter explanatory approach.

The certification mechanism works according to the subsequent principle: Given that outside investors believe in the information advantage of a third party (underwriter or venture capitalist), this party is able to certify the quality of a company going public if it has reputational capital at stake, "which must be greater than the largest possible one-time wealth transfer or side payment which could be obtained by certifying falsely. Furthermore it must be costly for the issuing firm to purchase the service of the certifying agent." (MEGGINSON/WEISS (1991, p. 881))

Underwriters and venture capitalists should be able to carry out the role of a certifying authority, as they often have insider information. The underwriting bank's information results from the involvement in due diligence activities and a potential lending relationship ${ }^{38}$ prior to the IPO. Their incentive to examine the quality of the firm in detail goes back to their liability extending to statements made in the issuing prospectus. ${ }^{39}$ Since venture capitalists belong to the actively engaged group of owners, they have profound knowledge about the company's history, quality of management, financial situation and so on. Moreover they involve themselves merely out of self-interest, due to the circumstance that their compensation is linked to the partnership's performance.

\footnotetext{
37 The authors hypothesis is, that given companies plan to carry out a seasoned equity offering, a separating equilibrium of high- and low-value firms exists, permitting high-value firms to costly signal their quality by underpricing. JENKINSON/LJUNGQVIST (1989) criticize, that the whole mechanism of the models using the level of underpricing as signal depends on a two-stage selling decision, which has to preclude shareholder's pre-emptive rights to seasoned offerings of primary equity, in order to recoup the costs of the signal.

${ }^{38}$ For an extensive discussion of the characteristics of relationship lending in Germany see ELSAS (2001).

${ }^{39}$ It has to be mentioned that this liability can lead to a considerable litigation and thus lawsuit risk. Therefore a competitive approach e.g. by TINIC (1988) suggests, that intentional underpricing may serve as an insurance against such securities litigation. For counterarguments see ALEXANDER (1993).
} 
Both parties have reputational capital at stake as their future success is closely linked to their current reputation. The better the reputation, the easier the attention of trading partners can be caught: Underwriters regularly have to attract issuers and venture capitalists frequently have to raise new funds.

One can therefore conclude that the involvement of a prestigious underwriter or venture capitalist should certify and credibly signal the quality of the issuing company to the market. I thus assume that it should pay to hire a prestigious intermediary, as it leads to a higher offer price, which in turn implies lower underpricing.

Going back to ROCK (1986), CARTER/MANASTER (1990) and BOOTH/SMITH (1986) the following hypotheses are formulated:

1. The higher the ex-ante uncertainty concerning the issue, the higher the expected underpricing.

2. The more prestigious the underwriter (UWrank) involved in the IPO, the lower the underpricing.

3a. The more prestigious the venture capitalist backing the company before the IPO (VCrank), the lower the underpricing.

Because the incentive to engage in the venture-backed company and thus the informative value of the signal "backed by a prestigious venture capitalist" depends in particular on the venture capitalist's equity holdings prior to the $\mathrm{IPO}^{40}$, hypothesis $3 \mathrm{a}$ should be narrowed down:

3b. The more prestigious the venture capitalist and the bigger the venture capitalist's equity holdings of the issuer prior to the going public (VCholding), the lower the underpricing.

Following LJUNGQVIST (1999) and BARRY (1989) a focus on underpricing alone possibly misleads: Underpricing per se is uninformative when not controlling for the former shareholders' incentives to influence underpricing. They will take influence on the pricing of an issue if their wealth is negatively affected by the price setting. Figuratively spoken, entrepreneurs and venture capitalists will not care for the wealth loss occurring through underpricing when selling a single share, but they will care the higher their participation in the

\footnotetext{
${ }^{40}$ This is in line with earlier findings of BARRY/MUSCARELLA/PEAVY/VETSUYPENS (1990).
} 
offering, i.e. the more shares they sell at the IPO. ${ }^{41}$ HABIB/LJUNGQVIST (1998) extend this idea $^{42}$ by assuming that the wealth loss of former shareholders at the IPO is a function of a) underpricing, when selling old shares, b) dilution of the value of retained shares ${ }^{43}$ and c) costs arising in connection with activities that reduce underpricing and wealth losses, such as extensive marketing efforts prior to the IPO or the hiring of IPO experts.

But this leads to an endogenous relation between the costs and underpricing. Since only aggregated figures of costs are available in most of the issuing prospectuses, the driving factors of these costs and with that their effect on underpricing are unclear. Therefore I dispense with costs as an explanatory variable and estimate a reduced form.

Finally hypothesis 4 is introduced:

4. The higher the participation ratio (partratio) of former shareholders (e.g. venture capitalists or managers, respectively) the lower the underpricing.

In line with LJUNGQVIST (1999) the dilution factor is taken into account, as well, when running the regressions. However, the predicted sign of this parameter is unclear.

Holding risk, dilution and participation constant and controlling for the quality of an underwriter I now should be able to analyze, whether venture capitalists are able to certify the quality of a company when going public.

\section{Data Set and Design of Analysis}

In total the collected data set contains 225 IPOs. Each of these companies were listed for the first time during the period of March $10^{\text {th }}, 1997$ to March $10^{\text {th }}, 2000$ on the Neuer Markt. The employed sample (comprising 199 IPOs) does not contain those 22 companies that merely changed the market tier or had already been listed at a foreign stock exchange before going public at the Neuer Markt. ${ }^{44}$ In addition, four companies, three of them from the financial

\footnotetext{
${ }^{41}$ The participation ratio (partratio) is calculated dividing the number of old shares sold by the number of shares outstanding before flotation.

${ }^{42}$ In the appendix I present the underlying model by BARRY (1989) and the extension by HABIB/LJUNGQVIST (1998).

43 The dilution factor (dilution) is determined dividing the number of new shares by the number of shares outstanding before flotation.

44 The following 22 companies have therefore been excluded: BB Biotech, BB Medtech AG, Bertrandt AG, Broad Vision Inc., COPE Inc., COR AG Insurance Technologies, Dialog Semiconductor Plc., DICOM Group, ebookers.com Plc., Fortec Electronik Vertriebs AG, GfN AG, integra S.A., LHS Group Inc., Lobster Technology Holding AG, Micronas Semiconductor Holding AG, Mühl Product \& Services AG, Pankl Racing Systems AG, Pfeiffer Vacuum Technology AG, Quiagen N.V., TEAM Communications Group Inc. and TIPTEL AG.
} 
services industry, have been excluded. These companies show extremely high values for balance sheet data or volume of issue. ${ }^{45}$

Given the differences in the definition of venture capital in the US and Germany, I establish comparability of the empirical studies by dividing the Neuer Markt data set into three groups: 108 non venture-backed IPOs (54.27\%), 58 venture-backed IPOs (29.15\%) and 33 companies $(16.58 \%)^{46}$, that merely received bridge financing by investors. As the latter investors typically have not invested seed, start-up and expansion capital next to bridge financing and therefore engage themselves at a rather late stage of the development of an company, the division made can be justified by the assumption that monitoring activities and thus the insider knowledge of these investors is of lower quality and thus of less worth with respect to their certification ability. ${ }^{47}$

In the descriptive study I therefore separately compare the venture-backed group and the sub sample of companies that received bridge financing to the non-venture backed group. ${ }^{48}$ Because of the focus on venture capitalists and their certification role, I concentrate on the venture and non venture-backed sub samples when testing the hypotheses. ${ }^{49}$

Detailed information was collected from the issuing prospectus for each IPO on the total volume of issues, the issuing procedure, the offering expenses, the number of shares outstanding, the age of the company, the number of employees, the ownership structure, who is members of the "Aufsichtsrat", the identity of invested venture capitalists or rather private equity companies and underwriters, and data of the financial statements.

Additionally, further information was obtained through the media such as the first day of trading, the book-building spread, the initial offering price and the closing day bid price for

\footnotetext{
45 These companies are ConSors Discount Broker, Direkt Anlage Bank AG, Entrium Direct Bankers AG and Carrier 1 International S.A..

${ }^{46}$ The sum of companies in the VC- and bridge financed group is lower than the number of venture-backed IPOs indicated by Deutsche Börse AG. The reason for this is that some of the backed IPOs have received equity as indicated by Deutsche Börse AG, which can neither be called venture capital nor private equity (including bridge financing). Instead, the capital theses companies received was offered by investment companies, e.g. by DEKA mbH., Rothschild Asset Management Ltd. or Invesco, without a selling intent. These IPOs have not been considered as backed IPOs.

${ }^{47}$ In order to find support for this assumption the monitoring skills of venture capitalists in comparison to those of bridge financiers are examined in more detail using proxies such as: the fraction of the issuing firm's shares owned by the venture capitalist/bridge financier or the length of time that a venture capitalist/bridge financier has served on the supervisory board, see table 4.

${ }^{48}$ For the results of the tests (for equality of means (t-test) and equality of median (Mann-Whitney) see table 3, 4 and table 6 .

49 But the results do not change qualitatively when treating the 33 bridge financed companies as non venturebacked companies, thus enlarging the database to be analyzed.
} 
the first day and 20 days after the IPO and information on the over-allotment option exercise (greenshoe).

To clearly identify the VC-firms and private equity companies and their age, internet pages and company reports (if available), as well as the list of the full members of Bundesverband Deutscher Kapitalbeteiligungsgesellschaften - German Venture Capital Association e.V. (BVK) and the European Venture Capital Association (EVCA) were used.

For the construction of the underwriter's rating the information needed on lead management at all Frankfurt stock market segments since 1990 was provided by Deutsche Börse AG.

A total of 86 different underwriters (48 different lead underwriters) have been involved in IPOs at Frankfurt stock exchange from March 1997 to March 2000. ${ }^{50}$ Because of the changing or rather increasing issuing activity during that time period I construct a rating for each year ${ }^{51}$. That is because the rating of an underwriter can change over time. The data of banks that merge during the investigation period (such as Bankhaus Gontard and Metallbank or Bayerische Vereinsbank and Bayerische Hypotheken- und Wechselbank) are aggregated in order to avoid major changes in the rating. However, changes in rating are desired in case of a relative increase of the issuing activity or a relative increase of the underwritten volume of issues. The parent population is divided into five rating categories and condensed to a dummy in the regressions. ${ }^{52}$ In detail, the ratings of the years 1998, 1999 and 2000 are constructed using equally the track record of each underwriter as gauged by the relative share of lead management at all Frankfurt stock market segments since $1990^{53}$ and the relative volume of launched issues at the Neuer Markt ${ }^{54}$ as reported on December $31^{\text {st }}$ of the precedent year. Due to the lack of a track record of the relative volume of launched issues at the Neuer Markt for

50 WASSERFALLEN/WITTLEDER (1994) stress the dominant role of Deutsche Bank in the underwriter market during the time period 1961 to 1987, since Deutsche Bank has functioned as lead manager for slightly less than half of the issues. This has changed during the time period 1990 to 2000. Although Deutsche Bank still belongs to the top issuers, their supremacy in underwriting has relatively been decreasing.

51 Table A.2. presents the twelve best-rated underwriters serving as lead underwriter at Neuer Markt during the time period $1997-2000$.

52 The dummy has the value one in case the underwriter's rating is very good; in any other case $(1.5,2,2.5$ or 3$)$ the dummy is equivalent to zero. From 199 IPO companies under consideration, 108 have been underwritten by a prestigious lead underwriter rated very good.

53 The relative share of lead management at all Frankfurt stock market segments for each year is calculated by cumulating the number of lead management for each bank since 1990 and dividing this number by the cumulated number of IPOs that took place since 1990.

${ }^{54}$ In order to calculate the relative volume of issues at the Neuer Markt for each bank I cumulate the volume of issues each bank has underwritten (as lead- or co-underwriter) since 1997 and divide it by the total volume of issues of all IPOs at the Neuer Markt since 1997. 
the year 1997, the rating of 1997 is solely based on each bank's relative share of lead management at all Frankfurt stock market segments since 1990.

However the (one) rating that represents the quality of the venture capitalists and private equity companies is mainly based on the age of the company. VC and private equity companies founded before 1980 receive a very good rating (equivalent to 1), companies founded before 1995 and after 1980 receive a mediate rating (equivalent to 2). Companies founded after 1995 get the lowest rating (equivalent to 3). For some companies it was impossible to find information regarding their age. In these cases the assumption of little prestige resulting in a low rating (equivalent to 3 ) seems to be reasonable. The motive for using first of all the age as proxy for reputation is that in general there is a lack of a past performance. This fact is reflected in a total of 112 venture funds/companies or private equity companies backing 91 IPO firms: 75 of these (66.96\%) back only one IPO firm, 32 (28.57\%) back between 2 and 5, and only $5(4.46 \%)$ back more than 5, up to 10 IPOs during the time period March 1997 - March 2000. Thus only in two cases ${ }^{55}$ a relative high backing activity during the period under consideration leads to an upgrade in rating. In analogy to the underwriters' rating, the information concerning the quality of the lead venture capitalist is condensed to a dummy in the regressions. ${ }^{56}$

In line with LJUNGQVIST (1999), the venture capitalist with the biggest stake (which usually corresponds with the longest investment horizon within the portfolio company) is defined as the lead venture capitalist. 54 of the 112 venture funds/companies or private equity companies act as lead financier, whereas the remaining 58 merely engage themselves within a syndicate.

\footnotetext{
${ }^{55}$ These financial intermediaries have been Commerz Unternehmensbeteiligungs AG and Gold Zack AG.

56 The dummy is equal to unity if the financier's rating is very good (this is the case in about one third of the 58 venture-backed IPOs or rather 33 IPOs backed by bridge financing); in any other case ( 2 or 3 ) the dummy is equivalent to zero. (Table A.3. in the appendix presents the eleven best rated venture capitalists during the time period March 1997 - March 2000).
} 


\section{Descriptive Statistics}

Table 3: Issuer and Offering Characteristics and Costs of Venture-Backed respectively Bridge Financed Companies to Non Venture-Backed Companies Listed at the Neuer Markt.

The data set consists of 108 non venture-backed IPOs (NVC), 58 venture-backed IPOs (VC) and 33 companies (BF) that received bridge financing. The participation ratio (for instance of the manager) is calculated by dividing the number of old shares sold (by the manager) by the (manager's) number of shares outstanding before flotation. Underpricing is measured as the spread between the initial offering price and the opening price at the first day of trading. NEMAX is the stock market index of the Neuer Markt at Frankfurt stock exchange. The test for differences in means is a standard $t$-test, allowing for unequal variance. The test for differences in medians is the Mann-Whitney test. One, two and three asterisks indicate significance at the $10 \%, 5 \%$ and $1 \%$ level, respectively.

\begin{tabular}{|c|c|c|c|c|c|c|}
\hline & & Obs. & Mean & $p$-value & Median & $p$-value \\
\hline \multirow[t]{3}{*}{ Employees } & $N V C$ & 108 & 250 & & 117 & \\
\hline & VC & 58 & 220 & 0.5788 & 110 & 0.8669 \\
\hline & BF & 32 & 197 & 0.4514 & 115 & 0.3771 \\
\hline \multirow[t]{3}{*}{ Age of company } & $N V C$ & 108 & 11 & & 9 & \\
\hline & VC & 58 & 10 & 0.3516 & 7 & 0.2208 \\
\hline & $\mathrm{BF}$ & 33 & 10 & 0.5449 & 9 & 0.6897 \\
\hline \multirow{3}{*}{$\begin{array}{l}\text { Balance sheet total, } \\
\text { in thousand } €\end{array}$} & $N V C$ & 108 & 26,365 & & 12,383 & \\
\hline & VC & 58 & 31,339 & 0.5577 & 11,538 & 0.8695 \\
\hline & BF & 32 & 13,922 & $0.0545^{*}$ & 8,286 & $0.0652^{*}$ \\
\hline \multirow{3}{*}{$\begin{array}{l}\text { EBIT in thousand } € \\
\text { per employee }\end{array}$} & $N V C$ & 108 & 26 & & 9 & \\
\hline & VC & 58 & -6 & $0.0023^{\star * \star}$ & -2 & $0.0002^{* * *}$ \\
\hline & BF & 31 & 3 & $0.0771^{*}$ & 4 & $0.0427^{* *}$ \\
\hline \multirow{3}{*}{$\begin{array}{l}\text { Sales revenues } \\
\text { in thousand } € \\
\text { per employee }\end{array}$} & $N V C$ & 108 & 269 & & 108 & \\
\hline & VC & 58 & 135 & $0.0299^{\star *}$ & 106 & 0.3277 \\
\hline & BF & 31 & 171 & 0.2416 & 100 & 0.5900 \\
\hline \multirow{3}{*}{$\begin{array}{l}\text { Growth rate } \\
\text { of sales revenues, } \\
\text { in \% }\end{array}$} & $N V C$ & 88 & 70.86 & & 44.21 & \\
\hline & VC & 47 & 86.96 & 0.5750 & 25.10 & 0.5134 \\
\hline & $\mathrm{BF}$ & 26 & 80.39 & 0.7602 & 54.65 & 0.7535 \\
\hline \multirow{3}{*}{$\begin{array}{l}\text { Total volume } \\
\text { of issues, } \\
\text { in thousand }\end{array}$} & $N V C$ & 108 & 1,962 & & 1,451 & \\
\hline & VC & 58 & 2,519 & $0.0735^{\star}$ & 1,870 & $0.0227^{* *}$ \\
\hline & $\mathrm{BF}$ & 33 & 1,939 & 0.9484 & 1,600 & 0.7222 \\
\hline \multirow{3}{*}{$\begin{array}{l}\text { Old stocks sold in \% } \\
\text { of total volume } \\
\text { of issues }\end{array}$} & $N V C$ & 108 & 16.35 & & 10.22 & \\
\hline & VC & 58 & 22.33 & $0.0547^{*}$ & 23.04 & $0.0637^{\star}$ \\
\hline & $\mathrm{BF}$ & 33 & 19.99 & 0.3071 & 22.12 & 0.1601 \\
\hline \multirow{3}{*}{$\begin{array}{l}\text { Participation old } \\
\text { stockholders }\end{array}$} & $N V C$ & 108 & 0.0600 & & 0.0357 & \\
\hline & VC & 58 & 0.1166 & $0.0002^{\star \star \star}$ & 0.0829 & $0.0049^{* * *}$ \\
\hline & $\mathrm{BF}$ & 33 & 0.0762 & 0.2446 & 0.0732 & 0.1474 \\
\hline \multirow{3}{*}{$\begin{array}{l}\text { Participation } \\
\text { managers }\end{array}$} & $N V C$ & 108 & 0.0681 & & 0.0451 & \\
\hline & VC & 58 & 0.0559 & 0.4007 & 0.0000 & $0.0198^{* *}$ \\
\hline & $\mathrm{BF}$ & 33 & 0.0333 & $0.0145^{\star *}$ & 0.0117 & $0.0044^{\star * *}$ \\
\hline \multirow[t]{3}{*}{ Underpricing in \% } & $N V C$ & 108 & 61.18 & & 26.46 & \\
\hline & VC & 58 & 64.63 & 0.8025 & 32.00 & 0.5902 \\
\hline & $\mathrm{BF}$ & 33 & 68.34 & 0.6690 & 38.86 & 0.2495 \\
\hline \multirow{3}{*}{$\begin{array}{l}20 \text { day log return of } \\
\text { NEMAX before IPO } \\
\text { in \% }\end{array}$} & $N V C$ & 108 & 5.72 & & 2.95 & \\
\hline & VC & 57 & 6.37 & 0.7942 & 1.48 & 0.8545 \\
\hline & $\mathrm{BF}$ & 33 & 4.86 & 0.7727 & -0.18 & 0.4622 \\
\hline
\end{tabular}


In terms of issuer characteristics, venture-backed companies differ most from non-venture backed with regard to EBIT and sales revenues in thousand EURO per employee. Both ratios are on average significantly smaller: -6 versus 26 and 135 versus 269 . Given no significant differences in the number of employees, in age, balance sheet total and in growth rates of sales revenues, there seems to be evidence that these otherwise comparable IPO companies are less profitable and less strong at selling when going public. This is remarkable.

At the first glance the findings concerning offerings characteristics are in line with the results of LJUNGQVIST (1999). Venture-backed IPOs show a significantly higher volume of issues compared to non venture-backed IPOs. In particular venture-backed companies sell more old shares when going public. This is reflected by an average of $22.33 \%$ versus $16.35 \%$ of secondary sales of the total volume issued, and by an on average higher participation ratio of old stockholders (11.66\% versus $6 \%$ of the shares outstanding before flotation). But - and that might have a reversal effect to venture-backers being more concerned with pricing - the median participation ratio of managers in venture-backed IPOs is zero and thus lower. To keep an eye on that and to differentiate between different groups of former stockholders, such as venture capitalists, managers and underwriters owning shares of the issuing company before the IPO seems to be worthwhile when running the regressions. ${ }^{57}$

Furthermore, the univariate analysis shows that venture-backed companies do not seem to be less underpriced compared to non venture-backed (see table 3).

Before turning to the empirical results I will briefly highlight some further characteristics of venture-backed companies that distinguish them from those which received bridge financing and justifies the three categories made: On average about $57 \%$ of the VC-backed companies have been financed by a syndicate before the IPO ${ }^{58}$, whereas issuing companies that received bridge financing dealt with more than one bridge financier only in one out of three cases (not reported).

Compared to the stake of the lead venture capitalist that of the lead bridge financier is on average significantly higher before $(26.48 \%$ versus $11.97 \%)$ and also after the IPO $(14.47 \%$ versus $6.61 \%)^{59}$. This fact is all the more true for the average stake of the syndicate of venture

\footnotetext{
${ }^{57}$ These groups do overlap as venture capitalists sometimes belong to the management.

58 On average a venture-backed company is financed by three, on maximum by nine different venture firms/funds.

59 The numbers are much higher compared to those stated by BARRY/MUSCARELLA/PEAVY/VETSUYPENS (1990) or HAMAO/PACKER/RITTER (2000).
} 
capitalists compared to the stake of the group of bridge financiers (before the IPO $40.48 \%$ versus $13.63 \%$; after the IPO $22.39 \%$ versus $7.87 \%$ ). In addition this means, that both groups of financial intermediaries sell on average $25 \%$ of their pre-IPO stake at the IPO which seems to be much higher than in the United States. ${ }^{60}$

Table 4: Characteristics of Financial Intermediaries and Offering Characteristics of Venture-Backed and Bridge Financed IPO Companies at the Neuer Markt.

The data set consists of 58 venture-backed IPOs (VC) and 33 companies (BF) that received bridge financing. The participation ratio (e.g., of the lead venture capitalist or bridge financier, respectively) is calculated by dividing the number of old shares sold (by the lead venture capitalist or bridge financier, respectively) by the (lead venture capitalist's and bridge financier's respectively) number of shares outstanding before flotation. The test for differences in means is a standard $t$-test, that allows differences in variance. The test for differences in medians is the Mann-Whitney test. One, two and three asterisks indicate significance at the $10 \%, 5 \%$ and $1 \%$ levels, respectively.

\begin{tabular}{|c|c|c|c|c|c|c|}
\hline & & Obs. & Mean & $p$-value & Median & $p$-value \\
\hline $\begin{array}{l}\text { Number of venture } \\
\text { capitalists or bridge } \\
\text { financiers forming a } \\
\text { syndicate } \\
\end{array}$ & $\begin{array}{l}\mathrm{VC} \\
\mathrm{BF}\end{array}$ & $\begin{array}{l}58 \\
33 \\
\end{array}$ & $\begin{array}{l}2.60 \\
1.36 \\
\end{array}$ & $0.0007^{* * *}$ & $\begin{array}{l}2.00 \\
1.00 \\
\end{array}$ & $0.0030^{* *}$ \\
\hline $\begin{array}{l}\text { Stake of lead venture } \\
\text { capitalist/ lead bridge } \\
\text { financier before IPO, } \\
\text { in } \%\end{array}$ & $\begin{array}{l}\text { VC } \\
B F\end{array}$ & $\begin{array}{l}57 \\
33\end{array}$ & $\begin{array}{l}26.48 \\
11.97 \\
\end{array}$ & $0.0002^{* * *}$ & $\begin{array}{l}20.00 \\
13.47\end{array}$ & $0.0002^{* \star *}$ \\
\hline $\begin{array}{l}\text { Stake of venture capitalists/ } \\
\text { bridge financiers before } \\
\text { IPO, in \% }\end{array}$ & $\begin{array}{l}\text { VC } \\
\text { BF }\end{array}$ & $\begin{array}{l}58 \\
33\end{array}$ & $\begin{array}{l}40.48 \\
13.63\end{array}$ & $0.0000^{* * *}$ & $\begin{array}{l}36.40 \\
13.85\end{array}$ & $0.0000^{* * *}$ \\
\hline $\begin{array}{l}\text { Stake of lead venture } \\
\text { capitalist/ lead bridge } \\
\text { financier after IPO, } \\
\text { in } \% \\
\end{array}$ & $\begin{array}{l}\text { VC } \\
\text { BF }\end{array}$ & $\begin{array}{l}57 \\
33\end{array}$ & $\begin{array}{r}14.47 \\
6.61 \\
\end{array}$ & $0.0003^{* * *}$ & $\begin{array}{r}11.44 \\
6.30\end{array}$ & $0.0001^{* * *}$ \\
\hline $\begin{array}{l}\text { Stake of venture capitalists/ } \\
\text { bridge financiers after IPO, } \\
\text { in \% }\end{array}$ & $\begin{array}{l}\text { VC } \\
B F\end{array}$ & $\begin{array}{l}58 \\
33\end{array}$ & $\begin{array}{r}22.39 \\
7.87 \\
\end{array}$ & $0.0000^{* * *}$ & $\begin{array}{r}21.30 \\
7.50 \\
\end{array}$ & $0.0000^{* * *}$ \\
\hline $\begin{array}{l}\text { Participation lead venture } \\
\text { capitalist/ } \\
\text { bridge financier }\end{array}$ & $\begin{array}{l}\text { VC } \\
\text { BF }\end{array}$ & $\begin{array}{l}57 \\
32\end{array}$ & $\begin{array}{l}0.2246 \\
0.2679\end{array}$ & 0.4223 & $\begin{array}{l}0.2034 \\
0.2404\end{array}$ & 0.7227 \\
\hline $\begin{array}{l}\text { Seats on the "Aufsichtsrat" } \\
\text { held by venture capitalists } \\
\text { or bridge financiers, in \% }\end{array}$ & $\begin{array}{l}\text { VC } \\
\text { BF }\end{array}$ & $\begin{array}{l}58 \\
33\end{array}$ & $\begin{array}{l}25.37 \\
14.09\end{array}$ & $0.0054^{* * *}$ & $\begin{array}{r}33.33 \\
0.00\end{array}$ & $0.0125^{\star *}$ \\
\hline \begin{tabular}{|l|} 
Duration of financial \\
relationship in years
\end{tabular} & $\begin{array}{l}\mathrm{VC} \\
\mathrm{BF}\end{array}$ & $\begin{array}{l}57 \\
33\end{array}$ & $\begin{array}{l}2.9649 \\
1.0303 \\
\end{array}$ & $0.0000^{\star \star \star}$ & $\begin{array}{l}2.0000 \\
1.0000\end{array}$ & $0.0000^{\star \star \star}$ \\
\hline \begin{tabular}{|l|} 
Dummy rating of lead \\
venture capitalist/ \\
bridge financier $=1$ \\
\end{tabular} & $\begin{array}{l}\text { VC } \\
\text { BF }\end{array}$ & $\begin{array}{l}58 \\
33\end{array}$ & $\begin{array}{l}0.3448 \\
0.3636\end{array}$ & 0.8586 & $\begin{array}{l}0.0000 \\
0.0000\end{array}$ & 0.8851 \\
\hline $\begin{array}{l}\text { Number of IPOs where } \\
\text { venture capitalists/ } \\
\text { bridge financiers do not } \\
\text { sell, in \% }\end{array}$ & $\begin{array}{l}\text { VC } \\
\text { BF }\end{array}$ & $\begin{array}{l}58 \\
33\end{array}$ & $\begin{array}{l}27.27 \\
20.69\end{array}$ & 0.4792 & $\begin{array}{l}0.00 \\
0.00\end{array}$ & 0.6059 \\
\hline
\end{tabular}

${ }^{60}$ According to a study by BARRY/MUSCARELLA/PEAVY/VETSUYPENS (1990) US venture capitalists own on average $34.3 \%$ prior and $24.6 \%$ after the IPO, thus they sell on average only $6.6 \%$ of their pre-IPO shares. 
Furthermore, venture capitalists are more likely to command over more inside information than bridge financiers, since the former hold an average of $25.37 \%{ }^{61}$ versus $14.09 \%$ of the seats on the "Aufsichtsrat". Besides venture capitalists have engaged themselves much longer in the issuing company before the IPO, namely about two years longer on average.

Taking the proportion of ownership and degree of insider knowledge into account the bridge financiers' certification ability seems to be modest. Therefore the results presented in the following are dispensed with the bridge financed sub sample.

\section{Empirical Results}

The determinants of underpricing are examined applying an ordinary least square regression analysis with underpricing as depended variable.

In order to measure the ex-ante uncertainty concerning the value of an IPO company two different proxies are used: In line with e.g. RITTER (1984) and WASSERFALLEN/WITTLEDER (1994), for each IPO company the standard deviation of the log returns from day two to twenty (vola) are calculated, which I expect to reflect the degree of dispersed information or rather uncertainty. Theory predicts a positive relation between uncertainty and underpricing. Since this proxy might be distorted due to underwriter price support in the aftermarket (see LJUNGQVIST (1997)) the log of the number of employees (empl) is included, as well. Large companies that go public and employ many people should be less underpriced than small companies. ${ }^{62}$ Following LJUNGQVIST/JENKINSON (2000) and LOUGHRAN/RITTER (1999), I calculate to what extend the book-building range (bookb) was exhausted. Issues priced at the maximum price limit, exhausting $100 \%$ of the book-building range, should be more underpriced compared to IPOs with an issue price that falls within the book-building range or below the minimum price limit.

Besides I use the market trend, a proxy LÖFFLER (2000) and earlier UHLIR (1989) employed in their examination of underpricing. The market trend is estimated using the NEMAX ${ }^{63}$ for the period twenty days before the IPO (nemax). As LÖFFLER documents, there seem to exist

\footnotetext{
${ }^{61}$ This number is lower as the one reported by BARRY/MUSCARELL/PEAVY/VETSUYPENS (1990).

${ }^{62}$ I also checked whether the age or the total volume of assets could serve as an explanatory variable for the amount of underpricing, but found no significant correlation.

${ }^{63}$ NEMAX is the stock market index of Neuer Markt at Frankfurt stock exchange. The introduction of this variable does not affect the other results found.
} 
(psychological/market) factors that lead to a significant positive relation between the trend of the Nemax and the degree of underpricing.

One can either apply a dummy for "backed by venture capital" or less condensed information, i.e., the percentage of the venture capitalists' equity holdings prior to the IPO (VCholding). Since it should make a difference whether a venture capitalist holds for instance $5 \%$ or $50 \%$ of a company prior to IPO, (as explained in section 4, see hypothesis $3 b$ ) I will use the latter.

With reference to the hypotheses discussed in section 4 , this leads to the following predicted signs for the regressions:

\begin{tabular}{|c|c|c|c|c|c|c|c|c|c|}
\hline & $\partial$ vola & dempl & dbookb & $\partial$ nemax & dUWrank & $\partial \mathrm{VCrank}$ & $\partial$ VCholding & $\partial$ partratio & ddilution \\
\hline$\partial$ UP & + & - & + & + & - & - & - & - & $?$ \\
\hline
\end{tabular}

The results are presented in table 5, page 21.

Columns (1) and (2) of table 5 ignore the incentive argument of LJUNGQVIST (1999) and thus resemble earlier studies, for instance the analysis of MEGGINSON/WEISS (1991). All parameter estimates that represent the degree of ex-ante uncertainty (vola, bookb) or size (empl) show the predicted signs on a significant level. The smaller the issuing company and the higher the standard deviation of the log returns from day two to twenty, the higher the underpricing. Moreover, the more the book-building range was exhausted, the higher the underpricing. These results are in line with earlier studies on the German market, such as WASSERFALLEN/ WITTLEDER (1994). The highly significant coefficient for the market trend (nemax) supports the findings of LÖFFLER (2000): The initial return rises on average about between $2.2 \%$ and $2.3 \%$ with each percentage point the log return of the Nemax is rising prior to the IPO.

Concerning the certification role of venture capitalists and underwriters, I do not find any support either for hypotheses 2 or 3.

On the contrary, companies that are backed by a prestigious venture capitalist experience greater underpricing: The coefficient VCrank=1 is positive and significant at the $10 \%$ or $5 \%$ level, respectively. Remarkably, there is no significant outcome when controlling for venture capitalists with a lower rating (not reported). However, the effect found seems to be obscured: When interacting the dummy for the rating of prestigious venture capitalists with the 
Table 5: Test of the Certification Hypotheses: Underpricing.

The dependent variable is underpricing. The variable vola is equivalent to the standard deviation of the log returns from day two to twenty prior to the IPO, emp/ represents the log of the number of employees, bookb reflects the extend to which the book-building range was utilized, nemax incorporates the market trend twenty days before the IPO. The variables UWrank=1 and VCrank $=1$ are dummies for underwriters and venture capitalists rated very good. VCholding presents the venture capitalist's equity holding prior to the IPO, partratio and dilut are explained in footnotes 41 and 43 , respectively. The variable nosal_VC is a dummy equal to 1 if the syndicate of venture capitalists does not sell shares at the IPO and zero otherwise. The dummy conflict is equal to 1 if the venture capitalist is affiliated with one of the (lead-) underwriters. Throughout, the interference is based on White's heteroskedasticity-consistent standard errors. One, two and three asterisks indicate significance at the $10 \%, 5 \%$ and $1 \%$ level, respectively. In columns 5 and 6 , the total effect of the presence of a prestigious venture capitalist is tested in an F-test.

\begin{tabular}{|c|c|c|c|c|c|c|}
\hline Variables: & (1) & (2) & (3) & (4) & (5) & (6) \\
\hline \multirow[t]{2}{*}{ constant } & 0.574 & 0.569 & 0.544 & $0.624^{*}$ & 0.527 & 0.542 \\
\hline & 0.1120 & 0.1161 & 0.1317 & 0.0939 & 0.1583 & 0.1519 \\
\hline \multirow[t]{2}{*}{ vola } & $4.194^{*}$ & $4.469^{\star \star}$ & $4.599^{\star *}$ & $4.262^{*}$ & $4.242^{*}$ & $4.303^{*}$ \\
\hline & 0.0611 & 0.0462 & 0.0418 & 0.0579 & 0.0580 & 0.0550 \\
\hline \multirow[t]{2}{*}{ empl } & $-0.112^{*}$ & $-0.108^{*}$ & $-0.109^{*}$ & $-0.115^{\star}$ & $-0.119^{*}$ & $-0.121^{*}$ \\
\hline & 0.0648 & 0.0760 & 0.0812 & 0.0639 & 0.0559 & 0.0533 \\
\hline \multirow[t]{2}{*}{ bookb } & $0.293^{\star \star \star}$ & $0.233^{\star \star}$ & $0.219^{\star \star}$ & $0.242^{\star \star}$ & $0.327^{\star \star \star}$ & $0.316^{\star \star \star}$ \\
\hline & 0.0057 & 0.0380 & 0.0487 & 0.0285 & 0.0020 & 0.0028 \\
\hline \multirow[t]{2}{*}{ nemax } & $2.302^{\star \star \star}$ & $2.238^{\star \star \star}$ & $2.241^{\star \star \star}$ & $2.283^{\star \star \star}$ & $2.309^{\star \star \star}$ & $2.314^{\star \star *}$ \\
\hline & 0.0000 & 0.0000 & 0.0000 & 0.0000 & 0.0000 & 0.0000 \\
\hline \multirow[t]{2}{*}{ UWrank=1 } & -0.050 & -0.033 & -0.037 & -0.039 & 0.009 & 0.010 \\
\hline & 0.6655 & 0.7744 & 0.7500 & 0.7371 & 0.9383 & 0.9301 \\
\hline \multirow[t]{2}{*}{ VCrank=1 } & $0.406^{*}$ & $0.856^{\star \star}$ & $0.869^{* \star}$ & $1.022^{\star \star}$ & $0.842^{* \star}$ & $0.896^{\star *}$ \\
\hline & 0.0781 & 0.0463 & 0.0443 & 0.0213 & 0.0384 & 0.0326 \\
\hline \multirow[t]{2}{*}{ VCholding } & -0.306 & -0.125 & -0.172 & 0.110 & -0.174 & -0.208 \\
\hline & 0.2187 & 0.6579 & 0.5903 & 0.7482 & 0.6173 & 0.5490 \\
\hline partratio_Old & & & $\begin{array}{l}0.088 \\
0.8860\end{array}$ & & & \\
\hline dilution_Old & & & $\begin{array}{l}0.090 \\
0.4362\end{array}$ & & & \\
\hline partratio_VC & & & & $\begin{array}{l}-0.331 \\
0.2997\end{array}$ & $\begin{array}{l}0.087 \\
0.8113\end{array}$ & $\begin{array}{l}0.126 \\
0.7249\end{array}$ \\
\hline dilution_VC & & & & $\begin{array}{l}-0.054 \\
0.3246\end{array}$ & $\begin{array}{l}-0.079 \\
0.1419\end{array}$ & $\begin{array}{l}-0.067 \\
0.2289\end{array}$ \\
\hline nosal_VC & & & & & $\begin{array}{l}0.566^{\star \star \star} \\
0.0093\end{array}$ & $\begin{array}{l}0.626^{\star \star \star} \\
0.0034\end{array}$ \\
\hline conflict & & & & & & $\begin{array}{l}-0.182 \\
0.4345\end{array}$ \\
\hline $\begin{array}{l}\text { Interaction term: } \\
\text { VCrank }=1 * \text { VCholding }\end{array}$ & & $\begin{array}{r}-1.080 \\
0.1187\end{array}$ & $\begin{array}{r}-1.089 \\
0.1178\end{array}$ & $\begin{aligned}-1.406^{*} \\
0.0542\end{aligned}$ & $\begin{aligned}-1.250^{*} \\
0.0681\end{aligned}$ & $\begin{array}{r}-1.315^{*} \\
0.0672\end{array}$ \\
\hline Adj. $R^{2}$ & $30.53 \%$ & $31.12 \%$ & $30.30 \%$ & $31.24 \%$ & $32.97 \%$ & $32.73 \%$ \\
\hline$p$-value ( $F$-statistic) & 0.0000 & 0.0000 & 0.0000 & 0.0000 & 0.0000 & 0.0000 \\
\hline F-test: VCrank & & & & & 0.0852 & 0.0701 \\
\hline Number of observations & 164 & 164 & 164 & 164 & 164 & 164 \\
\hline
\end{tabular}


percentage of the venture capitalist's equity holdings prior to the IPO, the interaction term is negative. ${ }^{64}$

Now, the overall finding of venture-backed issues appearing, if anything, to be more underpriced is in line with the results of LJUNGQVIST (1999) for the 1990's and those of FRANCIS/HASAN (2001) and SMART/ZUTTER (2000). Though it is in contrast with the results of Lin/SMITH (1998) or BARRY/MUSCARELla/PEAVY/VETSUYPENS (1990). The latter empirical studies show that the higher the venture capitalist's reputation (measured for example by the venture capitalist's age and the former backing activity), the lower the underpricing. I have re-estimated the regression using other factors that usually serve as proxies for the monitoring or backing-quality of venture capitalists, such as the natural logarithm of the age of the lead venture capitalist at IPO, the number of seats on the "Aufsichtsrat" held (in percent) and the age of the financial relationship. Unfortunately I did not get any further insights. Since the venture capitalists' rating is based on the age of the lead venture capitalists, it is not astonishing that this coefficient behaves equivalent to the dummy for the VC-rating: it is positive and significant. Concerning the other two coefficients, they are not statistically significant.

With regard to the marginal effect of underwriter reputation I have to observe a general lack of significance of the coefficients. This suggests that companies, that have hired a prestigious lead underwriter when floating stocks are not better off than others. This result corresponds to earlier findings of KASERER/KEMPF (1995) for the German market. As expected, I obtain the same result when adding a term to the regression that interacts the rating of the underwriter with that of the venture capitalist (not reported).

Following LJUNGQVIST (1999) and BARRY (1989) I have introduced the participation ratio (serving as proxy for the selling intensity at IPO) and the dilution factor of the former shareholders in column (3) and subsequent columns of table 5. Since the data have been available I could control for the incentives of the group of the former shareholders as a whole, for the managers (not reported) and venture capitalists separately.

But due to the lack of significance - irrespectively of the identity of the group controlled for I am not able to confirm the results found by LJUNGQVIST (1999). There is no evidence for

\footnotetext{
${ }^{64}$ Though this term is only significant when controlling for the venture capitalists incentives to take influence on underpricing (see table 5, column (4)).
} 
underpricing to be lower due to incentives of former owners with a high selling intensity at the IPO.

In summary, no certification effect at the IPO could be found for venture capitalists or underwriters. Furthermore, there is no evidence that former stockholders selling shares at the IPO are particularly concerned about wealth loss and thus take influence on the pricing of an issue. Only hypothesis (1), which offers ex-ante uncertainty as a factor that determines underpricing finds considerable support.

\section{Extensions}

The question is why issues backed by prestigious venture capitalists appear to be more underpriced.

It seems to be puzzling, but similar results have been found before. FRANCIS/HASAN (2001) analyze a data set of companies going public in the United States during the period 1990 1993 using a stochastic frontier model. They show that VC-backed IPOs suffer higher underpricing due to greater pre-market pricing inefficiencies, which are to a significant part deliberate and should compensate investors for information production. The study by SMART/ZUTTER (2000) examines dual- and single-class IPOs and indicates underpricing to be more pronounced among VC-backed companies, too. They attribute this result to the circumstance that an increasing number of IPO companies has been financed by younger VC companies, that possibly engage in "grandstanding" 65 by taking their companies earlier to the market and at a larger discount than do established VCs.

LJUNGQVIST (1999), who analyzes a 1990s data set of IPOs, finds evidence that top underwriters are associated with significant increases in underpricing. An effect, which is in particular concentrated amongst venture-backed IPOs. But why do venture capitalists choose to work with prestigious investment banks whose pricing is so much worse? LJUNGQVIST offers an explanation: There are situations, that are characterized by a conflict of interest between entrepreneur and venture capitalist. He considers the case, that the entrepreneur sells some shares at the IPO but the lead venture capitalist none. In such situation the venture capitalist is not concerned about engaging a prestigious underwriter who underprices more than the average, since the incurring wealth losses have to be borne primarily by the selling owner rather than by himself.

\footnotetext{
${ }^{65}$ For an intense study on the phenomenon "grandstanding", see GOMPERS (1996).
} 
In my sample, in particular IPOs backed by prestigious or rather older venture capitalists are considerably more underpriced than IPOs that belong to any other segment. On average they are underpriced by $91.07 \%$ compared to $50.71 \%$ when backed by a less prestigious, younger venture capitalist or $61.18 \%$ when non venture-backed. It is surprising as these companies seem to be relatively large with respect to balance sheet totals and employees. Moreover this result contradicts the idea of "grandstanding" and thus the explanation offered by SMART/ZUTTER (2000). It thus seems to be rather interesting to analyze, whether the significant differences in underpricing can be explained by a non-selling behavior of venture capitalists, too.

Table 6: Characteristics of IPOs Backed by Prestigious Venture Capitalists (PVC) and Those With Lower Reputation (NPVC) at the Neuer Markt

\begin{tabular}{|lrc|c|c|c|c|}
\hline & & Obs. & Mean & $p$-value & Median & $p$-value \\
\hline Underpricing in \% & PVC & 20 & 91.07 & $0.0632^{*}$ & 46.55 & 0.1547 \\
& NPVC & 38 & 50.71 & & 25.98 & \\
\hline No sale & PVC & 20 & 30.00 & 0.3234 & 0.00 & 0.4767 \\
venture capitalists & NPVC & 38 & 18.42 & & 0.00 & \\
\hline Employees & PVC & 20 & 347 & $0.0076^{\star \star \star}$ & 193 & $0.0355^{\star \star}$ \\
& NPVC & 38 & 152 & & 97 & \\
\hline Balance sheet total, & PVC & 20 & 36,521 & 0.7017 & 23,547 & $0.0012^{\star * *}$ \\
in thousand $€$ & NPVC & 38 & 28,612 & & 9,273 & \\
\hline
\end{tabular}

The descriptive statistic shows that $30 \%$ of the prestigious and still about $18.4 \%$ of the lowest rated venture capitalists do not sell at IPO. These are 13 out of $58 \mathrm{VC}$-backed cases in total. In column (5) of table 5 I re-estimated the previous regression including a dummy for venture capitalists not selling at the IPO (nosal_VC). Indeed, the impact of such a non-selling behavior of venture capitalists is in any case (regardless of the rating) a significant increase in underpricing. This result is robust but does not solve the original puzzle, since the coefficient for the dummy of IPOs backed by prestigious venture capitalists remains significant and positive, though smaller.

A further explanation why VC-backed IPOs are more underpriced is offered by HAMAO/PACKER/RITTER (2000). These authors examine IPOs in Japan. In Japan, venture 
capital funds are often affiliated with major financial institutions. This circumstance can lead to potential conflicts of interest, since the underwriting bank, if an owner of the issuing company, is interested in setting a higher offer price than it would if it was merely acting as a financial intermediary. Furthermore, these banks have increased incentives to overstate the company value to investors. Given that IPO investors do anticipate this conflict of interest, they will, according to theory, demand more underpricing as compensation. In line with this, HAMAO/PACKER/RITTER find higher initial returns for IPOs in which the lead venture capitalist is also the lead underwriter. ${ }^{66}$ Although affiliations between venture capitalists and underwriting banks exist in Germany, too, ${ }^{67}$ they are not as common as in Japan. I have tried to control for this phenomenon of affiliation for the German market, though I have only eleven observations in my data set. However, the result lacks of significance and thus does not support this explanatory approach (see table 5, column 6).

Even though I could demonstrate that the non-selling behavior of venture capitalists drives underpricing, the appearance of IPOs backed by prestigious venture capitalists being more underpriced deserves further examinations.

Finally I would like to conclude with an illustration of the relative effect of underpricing on the venture capitalist's return on investment when selling at IPO:

A major German venture capitalist provided data on the historical costs of the shares of four IPO companies in my data set. I calculated the approximate return ${ }^{68}$ from investment until IPO, using the offering price $(O P)$ and the closing price $(C P)$ on the first trading day. ${ }^{69}$

Table 7: Returns on Four Investments of one Major German Venture Capitalist

\begin{tabular}{|l|c|c|c|c|}
\hline & A & B & C & D \\
\hline Return OP & $258 \%$ & $132 \%$ & $200 \%$ & $519 \%$ \\
\hline Return $C P$ & $294 \%$ & $182 \%$ & $530 \%$ & $506 \%$ \\
\hline
\end{tabular}

66 Apart from this special case mentioned, HAMAO/PACKER/RITTER (2000) find that VC-backed IPOs exhibit a significant reduction in underpricing relative to other issues.

67 Examples are Deutsche Venture Capital Gesellschaft and Deutsche Bank, Beteiligungsgesellschaft für die Deutsche Wirtschaft and Dresdner Bank AG, TFG Venture Capital and Concord Effekten AG or Commerz Unternehmensbeteiligungs AG and Commerzbank AG.

68 As no information regarding the exact date of the initial investment is available, I am not able to calculate a time-adjusted return.

69 In cases $\mathrm{A}, \mathrm{B}$ and $\mathrm{C}$, the offering price was fixed at the maximum price limit. In case $\mathrm{D}$, which was overpriced, the offering price was fixed at the lower bound of the book-building range. 
As easily can be seen, each of these investments was a success story for the venture capitalist, which partially was realized through selling at IPO. ${ }^{70}$ But at least in the first three cases the good result was accompanied by the knowledge, that the return on investment could have been better, if there had been no underpricing.

Given, for the period under consideration the four companies above are a good example for an IPO portfolio of a venture capitalist in Germany, I would like to formulate some hypotheses, that could serve as further explanations for the findings of my empirical study and should therefore be tested in future:

Venture capitalists seem not to care particularly about underpricing, as the bad news of money left on the table comes as part of a package that includes the good news of a successful partial exit. ${ }^{71}$ Moreover venture capitalists seem to be more concerned about the long-run performance and the timing of the further exit, since they retain on average three-quarters of their shares beyond the IPO-date. ${ }^{72}$

\section{Summary and Outlook}

The main contribution of this empirical study is to shed further light on the growing importance of venture capital in Germany after the introduction of the Neuer Markt at the Frankfurt Stock Exchange. In particular the role of venture capitalists and underwriters in certifying the quality of a company when going public is examined.

Papers by CARTER/MANASTER (1990) and BOTH/SMITH (1986) argue, that the spread between the initial offering price and the opening price on the first day of trading (underpricing) should be lower for venture-backed IPOs compared to non venture-backed IPOs due to a reduced exante uncertainty concerning the value of the issuing company.

However, to focus only on underpricing might be misleading. According to LJUNGQVIST (1999) the behavior of old shareholders at the IPO is essential. The more they participate in the offering, that is the more shares they are selling at the IPO, the more they have incentives to take influence leading to a reduced underpricing.

\footnotetext{
${ }^{70}$ As mentioned, on average venture capitalists sell $25 \%$ of their pre-IPO stake. Dividing the group into venture capitalists that sell and those that do not sell, the venture capitalists who sell shares at the IPO, sell on average about $32 \%$. Only in one case the venture capitalist sold $100 \%$.

71 A similar argumentation based on the prospect theory can be found by LOUGHRAN/RITTER (1999).

72 For empirical studies on the U.S. market see for instance BRAV/GOMPERS (1997)
} 
When running the regressions to test the hypotheses that venture-backed IPOs are less underpriced compared to non venture-backed IPOs, I control for ex-ante uncertainty, for the market trend, for the venture-capitalists' share of the company prior to the IPO, and, taking Ljungqvist's argument into account, for the incentives of old shareholders to reduce underpricing.

Turning to the results of this study, the huge number of financial intermediaries engaged in IPOs at Neuer Markt is worth mentioning: 86 underwriters and 112 venture capitalists or rather private equity companies.

Concerning the companies that went public at the Neuer Markt, I found that VC-backed companies are less profitable and have lower sales revenue-ratios compared to non venturebacked companies. Though, they are similar with respect to number of employees, age, balance sheet total, growth rates of sales revenues or the amount of underpricing. Venturebacked firms issue significantly more shares compared to non venture-backed ones. However, this difference might be attributed to the circumstance that VC-backed companies sell more old shares when going public. The fact that the group of venture capitalists sells an average $25 \%$ of their pre-IPO stake at the IPO supports this assumption.

More than half of the VC-backed companies have been financed by a syndicate of venture capitalists. They seem to have considerable influence, since they hold on average a stake of $40 \%$ of the company before the IPO and about $25 \%$ of the seats on the "Aufsichtsrat".

With reference to the results of the regressions, there is strong evidence that the higher the exante uncertainty about the value of a company going public the higher the underpricing. Furthermore, the market trend has a non-negligible positive impact on the amount of underpricing. However, the use of this variable does not affect the other results found.

With regard to the certification role of underwriters and/or venture capitalists, I am unable to provide evidence. It does not seem to pay to hire a prestigious intermediary, at least as far as underpricing is concerned. On the contrary: The involvement of a prestigious venture capitalist leads to a higher underpricing. This finding holds, irrespective of whether I control for venture capitalist not selling at the IPO (following the argumentation of LJUNGQVIST (1999)) or for conflicts of interest due to an affiliation of the venture capitalist and the underwriting bank (in line with HAMAO/PACKER/RITTER (2000)). The finding that prestigious venture capitalists appear to lead to more underpricing, warrants further research. 
When interpreting theses results one has to keep in mind that the data set under consideration was collected in a period, that can be characterized as a bull market. With the end of the examined period, i.e., since March 2000, there has been a sharp depression at the Neuer Markt along with a relative decline in IPOs. It would be worthwhile to enlarge the sample to check whether in bear markets a value of certification either through underwriters or venture capitalists exists. Moreover, this would allow to study the effect of an affiliation between underwriter and venture capitalist based on more observations.

In addition, since venture capitalists only sell on average about $25 \%$ of their shares at the IPO, an examination of their further exit strategy would be of utmost interest. Not least as the (timing of the) exit seems to be decisive for the venture capitalist's return on investment and thus the building up of further reputation.

Moreover, an extensive study of the direct costs that arise when going public at Neuer Markt seems to be worthwhile. Since on average companies going public at Neuer Markt have to bear direct costs of $8.43 \%$ of the gross proceeds, it would be interesting to know in how far these costs are of discretionary nature (e.g. costs derived from pre-IPO marketing activities) and thus could be used in order to reduce underpricing. 


\section{Appendix Figures:}

Figure A.1: Business Foundations in Western Germany; since 1990 in the Old West and

Newly-Formed German States (in Numbers of Newly Established Businesses) ${ }^{73}$

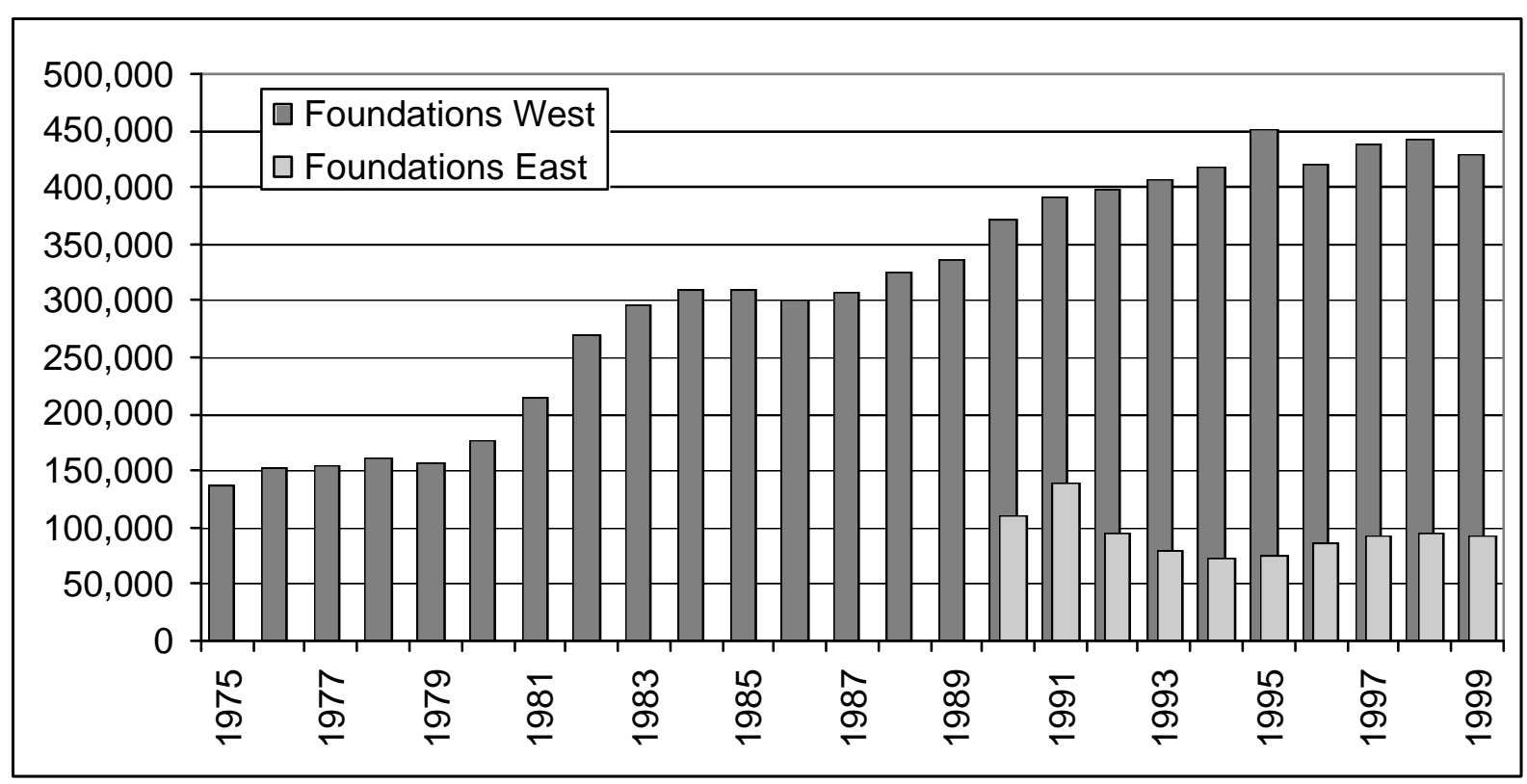

Figure A.2: Development of Gross Investments of Members of the BVK (in $€$ Mio.) and Number of Beneficiary Companies

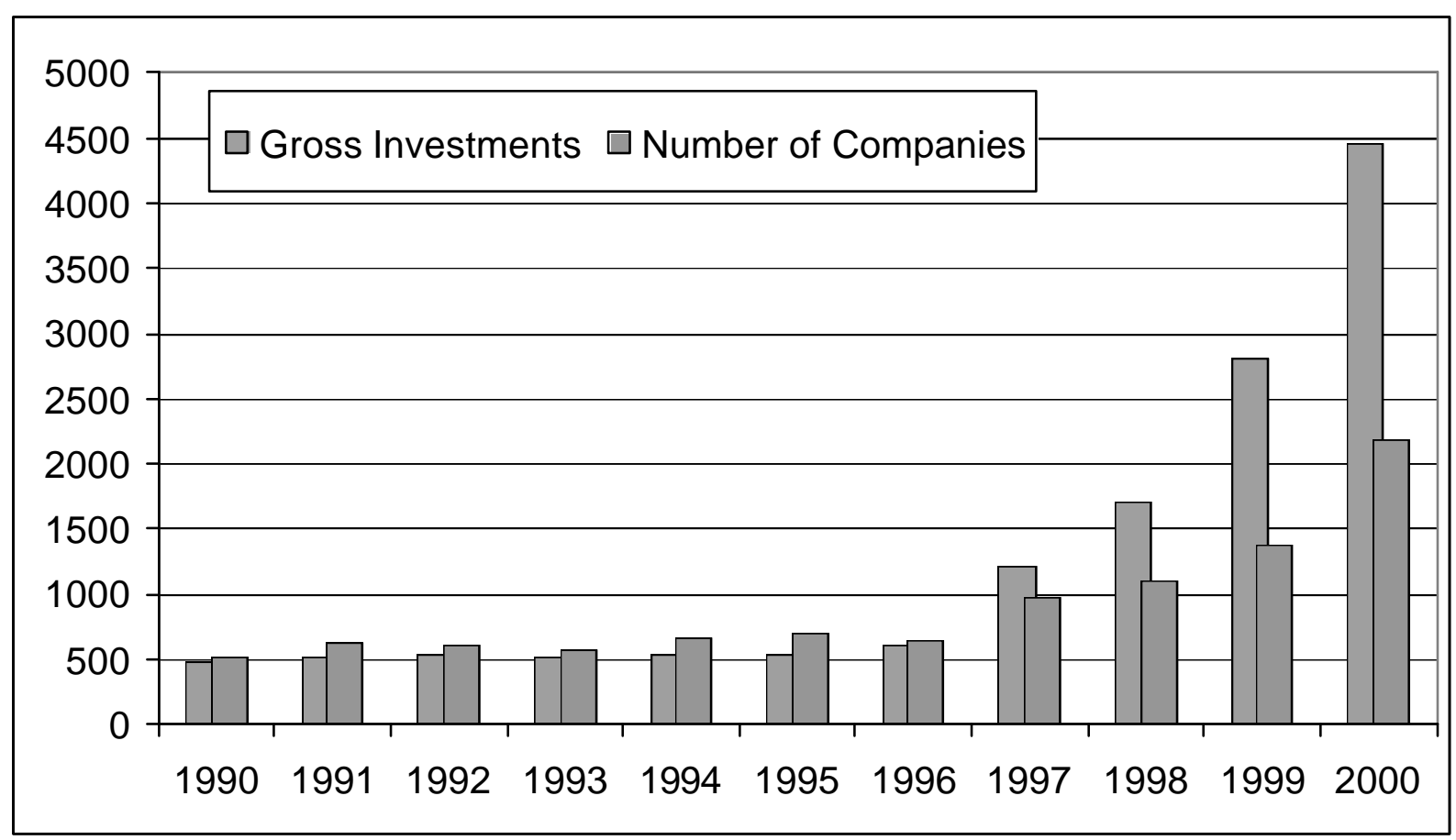

\footnotetext{
73 These numbers are estimations of the INSTITUT FÜR MITTELSTANDSFORSCHUNG (IFM).
} 


\section{Appendix Tables:}

Table A.1: Data Set Neuer Markt - March 10, 1997 - March 10, 2000

\begin{tabular}{|c|c|r|c|r|r|r|c|}
\hline & $\begin{array}{c}\text { Number of } \\
\text { Venture- } \\
\text { Yeacked IPOs }\end{array}$ & VC in \% & $\begin{array}{c}\text { Number IPOs } \\
\text { Backed by } \\
\text { Bridge } \\
\text { Financing }\end{array}$ & BF in \% & $\begin{array}{c}\text { Number of } \\
\text { Non Venture- } \\
\text { Backed IPOs }\end{array}$ & NVC in \% & Total \\
\hline 1997 & 6 & $54.55 \%$ & 1 & $9.09 \%$ & 4 & $36.36 \%$ & 11 \\
\hline 1998 & 9 & $21.95 \%$ & 9 & $21.95 \%$ & 23 & $56.10 \%$ & 41 \\
\hline 1999 & 37 & $29.37 \%$ & 19 & $15.08 \%$ & 70 & $55.56 \%$ & 126 \\
\hline 2000 & 6 & $28.57 \%$ & 4 & $19.05 \%$ & 11 & $52.38 \%$ & 21 \\
\hline Total & 58 & $29.15 \%$ & 33 & $16.58 \%$ & 108 & $54.27 \%$ & 199 \\
\hline
\end{tabular}

Table A.2: The Twelve Best Rated Underwriters Serving as Lead Underwriter at the Neuer Markt During the Time Period 1997 - 2000

The underwriter rating of the year 1997 is based on the relative share of lead management at all Frankfurt stock market segments since 1990; ratings of the years 1998, 1999 and 2000 are using equally weighted the track record of each underwriter concerning the relative share of lead management at all Frankfurt stock market segments since 1990 and the relative volume of launched issues at the Neuer Markt since 1997. A top rating is equivalent to one, the lowest rating equals the value of 3 .

\begin{tabular}{|c|c|c|c|c|}
\hline Underwriter & $\begin{array}{c}\text { Rating } \\
1997\end{array}$ & $\begin{array}{c}\text { Rating } \\
1998\end{array}$ & $\begin{array}{c}\text { Rating } \\
1999\end{array}$ & $\begin{array}{l}\text { Rating } \\
2000\end{array}$ \\
\hline Commerzbank AG & 1 & 1 & 1 & 1 \\
\hline Deutsche Bank AG & 1 & 1 & 1 & 1 \\
\hline $\begin{array}{l}\text { Bayerische Hypo- und Vereinsbank AG } \\
\text { (Bayerische Hypotheken- u. Wechselbank / } \\
\text { Bayerische Vereinsbank) }\end{array}$ & 1 & 1.5 & 1 & 1 \\
\hline BHF-Bank AG & 1 & 1.5 & 1 & 1 \\
\hline DG BANK AG & 2 & 1 & 1 & 1 \\
\hline Dresdner Bank AG & 2 & 1 & 1 & 1 \\
\hline West LB Girozentrale & 2 & 1 & 1 & 1 \\
\hline Goldman, Sachs \& Co. OHG & 2 & 2 & 1 & 1 \\
\hline Bankgesellschaft Berlin AG & 1 & 2 & 1.5 & 1.5 \\
\hline $\begin{array}{l}\text { Gontard \& MetallBank AG (Heinrich Gontard \& } \\
\text { Co. OHG / Metallbank GmbH) }\end{array}$ & 3 & 2 & 1.5 & 1 \\
\hline Sal. Oppenheim jr. \& Cie. KgaA & 3 & 2.5 & 1.5 & 1 \\
\hline HSBC Trinkaus \& Burkhardt KgaA & 2 & 2 & 2 & 1 \\
\hline
\end{tabular}


Table A.3: The Eleven Best Rated Venture Capitalists / Private Equity Companies Backing Companies that Went Public

at Neuer Markt During the Period March 1997 - March 2000

The rating representing the quality of the venture capitalists and private equity companies is mainly based on the age of the company. Venture capitalists and private equity companies founded before 1980 received a very good rating (equal to 1), companies founded before 1995 and after 1980 received a mediate rating (equivalent to 2). Companies founded after 1995 got the lowest rating (equivalent to 3). Thus only in two cases (Commerz Unternehmensbeteiligungs AG and Gold Zack) an relative high backing activity during the time period under consideration leads to an upgrade in rating.

\begin{tabular}{|c|c|c|c|}
\hline VC / private equity companies & Founded in & $\begin{array}{l}\text { Number of } \\
\text { backed IPO } \\
\text { companies }\end{array}$ & Rating \\
\hline 3i Group Plc. /3i Deutschland & 1945 & 10 & 1 \\
\hline Apax Partners \& Co. Beteiligungsberatung AG & 1969 & 5 & 1 \\
\hline Atlas Venture Germany & 1980 & 4 & 1 \\
\hline $\begin{array}{l}\text { BdW Beteiligungsgesellschaft für die deutsche } \\
\text { Wirtschaft mbH \& Co. KG }\end{array}$ & 1969 & 2 & 1 \\
\hline Deutsche Beteiligungs(gesellschaft) AG & 1965 & 2 & 1 \\
\hline General Atlantic Partners & 1980 & 1 & 1 \\
\hline Goldman Sachs Group, L.P. & 1950 & 1 & 1 \\
\hline Gold-Zack AG & 1990 & 10 & 1 \\
\hline Commerz Unternehmensbeteiligungs AG & 1987 & 6 & 1 \\
\hline Schroders Ltd. & 1957 & 3 & 1 \\
\hline $\begin{array}{l}\text { WestKB } \\
\text { Westdeutsche Kapitalbeteiligungs } \mathrm{mbH}\end{array}$ & 1969 & 1 & 1 \\
\hline
\end{tabular}




\section{Appendix}

Model of BARRY (1989), extended by HABIB and LJUNGQVIST(1998):

Consider a company that has $\left(S_{0}\right)$ shares outstanding prior to going public and that issues $\left(S_{N}\right)$ new shares at the IPO. In such a case the former shareholders suffer a wealth loss due to underpricing and dilution. The amount of wealth loss is inter alia dependent on the participation ratio and the dilution factor.

The participation ratio (partratio) is the ratio of the number of old shares sold $\left(S_{0, S}\right)$ to the number of shares outstanding before the flotation $\left(S_{0}\right)$. The dilution factor (dilution) is the ratio of new shares $\left(S_{N}\right)$ to the number of shares outstanding before the flotation $\left(S_{0}\right)$.

$$
\text { partratio } \equiv \frac{S_{0, S}}{S_{0}} \quad \text { dilution } \equiv \frac{S_{N}}{S_{0}}
$$

Let $\left(P_{0}\right)$ be the initial offer price, and let $\left(P_{1}\right)$ be the opening price at the first day of trading. In an efficient-market, this opening price at the first day of trading should reflect the (unobservable) value of the company prior to the IPO $\left(S_{0} P^{*}\right)$ plus the value of the money raised through flotation (ignoring the commission and other direct costs of going public):

$$
\begin{aligned}
& P_{1}=\frac{\left(S_{0} P^{*}+S_{N} P_{0}\right)}{\left(S_{0}+S_{N}\right)} \quad \text { by transformation this is equivalent to } \\
& P^{*}=P_{1}+\underbrace{\frac{S_{N}}{S_{0}}\left(P_{1}-P_{0}\right)}_{\text {dilution }}
\end{aligned}
$$

The smaller the offering in relation to the number of shares previously outstanding, the smaller the dilution effect. Thus the aggregated wealth loss of the former stockholders per old share $(a w l)$ is equivalent to:

$$
\begin{aligned}
a w l & \equiv\left[S_{0, S}\left(P^{*}-P_{0}\right)+\left(S_{0}-S_{0, S}\right)\left(P^{*}-P_{1}\right)\right]: S_{0} \\
& \equiv \underbrace{\operatorname{part}\left(P^{*}-P_{0}\right)}_{\text {participaiton }}+\frac{\left(S_{0}-S_{0, S}\right)}{S_{0}}\left(P^{*}-P_{l}\right)
\end{aligned}
$$


Given that the offering is underpriced, that is $\mathrm{P}^{*}>\mathrm{P}_{1}>\mathrm{P}_{0}$, old shareholders suffer the greatest aggregate wealth loss when selling all of their shares in the IPO. In summary, former owners "will be more concerned with underpricing as the size of the issue grows (relative to their own holdings) or as they participate more by offering more of their own shares" (BARRY (1989), p. 1102).

The extension of this model takes the possibility of costly actions into consideration, namely actions that influence the offer prices and thus reduce underpricing and wealth losses. Such costs (exp) could for example arise in connection with extensive marketing efforts prior to the IPO. These costs have to be add to the aggregated wealth loss arising from underpricing and dilution. Former shareholders therefore are assumed to minimize these so called total wealth losses per old share $(t w l)$ :

$$
t w l \equiv a w l+\exp
$$

"There is a trade-off between spending more (higher exp) and tolerating higher underpricing. At the optimum, the marginal effect of increasing exp to reduce underpricing should equal the marginal costs of doing so, implying that total wealth losses are invariant, at optimum, to exp.” (see LJUNGQVIST (1999), p. 6). 


\section{References}

[1] Alexander, J.C. (1993): The Lawsuit Avoidance Theory of Why Initial Public Offerings are Underpriced, in: UCLA Law Review, Vol. 17, pp. 17-23

[2] Allen, Franklin / Faulhaber, G. R. (1989): Signaling by Underpricing in the IPO Market, in: Journal of Financial Economics, Vol. 23, pp. 303-323

[3] Balzer, Karin (2000): Die Bedeutung des Venture Capital für innovative Unternehmen, Aachen, Shaker Verlag

[4] Barry, Christopher B. (1989): Initial Public Offering Underpricing: The Issuer's View - A Commment, in: Journal of Finance, Vol. 44, No.4, pp. 1099 - 1103

[5] Barry, Cristopher B. / Muscarella, Chris J. / Peavy III, John W. / Vetsuypens, Michael R. (1990): The Role of Venture Capital in the Creation of Public Companies, in: Journal of Financial Economics, Vol. 27, pp. 447-471

[6] Becker, Ralf / Hellmann Thomas (2000): The Genesis of Venture Capital: Lessons from the German Experience, Working Paper

[7] Betsch, Oskar / Groh, Alexander P. / Schmidt, Kay (2000): Gründungs- und Wachstumsfinanzierung innovativer Unternehmen, München, Oldenbourg

[8] Black, Bernard S. / Gilson, Ronald J. (1998): Does Venture Capital Require an Active Stock Market? Working Paper

[9] Booth, James R. / Smith, Richard L. II (1986): Capital Raising, Underwriting and the Certification Hypothesis, in: Journal of Financial Economics, Vol. 15, pp. 261-281

[10] Brav, Alon / Gompers, Paul A. (1997): Myth or Reality? The Long-run Underperformance of Initial Public Offerings: Evidence from Venture and Nonventure Capital-Backed Companies, in: Journal of Finance, Vol. 52, pp. 1791-1821

[11] Brennan, Michael J. / Franks, Julian (1997): Underpricing, Ownership and Control in Initial Public Offerings of Equity Securities in the UK, in: Journal of Financial Economics, Vol. 45, pp. 391-413

[12] Bygrave, William D. / Timmons, Jeffry A. (1992): Venture Capital at the Crossroads, Boston

[13] Carter, Richard / Manaster, Steven (1990): Initial Public Offerings and Underwriter Reputation, in: Journal of Finance, Vol. 45, No.4, pp. 1045-1067

[14] DAI-Factbook (2000), published by Deutsches Aktieninstitut e.V. (DAI), Frankfurt

[15] Die Bank Survey (2000): Aktienkultur: Volk der Aktionäre?, in: Die Bank, 10/2000, pp. 710-711

[16] Ehrhardt, Olaf (1997): Börseneinführungen von Aktien am deutschen Kapitalmarkt, Gabler Verlag, Wiesbaden

[17] Elsas, Ralf (2001): Die Bedeutung der Hausbank - Eine ökonomische Analyse, Gabler Verlag, Wiesbaden

[18] Fenn, George W. / Liang, Nellie / Prowse, Stephen (1997): The Private Equity Market: An Overview, in: Financial Markets, Institutions and Instruments, Vol. 6, No. 4 
[19] Francis, B. Bill / Hasan, Iftekhar (2001): The Underpricing of Venture and Nonventure Capital IPOs: An Empirical Investigation, in: Journal of Financial Services Research, Vol. 19, No. 2/3, pp. 93-113

[20] Gerke, Wolfgang / Bosch, Robert (2000): Designated Sponsors im Xetra-Handel eine empirische Analyse, Working Paper

[21] Gompers, Paul A. (1996): Grandstanding in the Venture Capital Industry, in: Journal of Financial Economics, Vol. 42, pp. 133-156

[22] Grinblatt, Mark / Hwang, Chuan Y. (1989): Signaling and the Pricing of New Issues, in: Journal of Finance, Vol. 44, pp. 393-420

[23] Habib, Michel A. / Ljungquist, Alexander P. (1998): Underpricing and Entrepreneurial Wealth Losses in IPOs: Theory and Evidence, Working Paper

[24] Hamao, Yasushi / Packer, Frank / Ritter Jay R. (2000): Institutional Affiliation and the Role of Vent ure Capital: Evidence from Initial Public Offerings in Japan, in: PacificBasin Finance Journal, Vol. 8, pp. 529-558

[25] Heilmann, Dirk Hinrich (2000): US-Wagniskapitalfonds drängen nach Europa, Handelsblatt, 19.6.2000, pp. 18

[26] Jeng, Leslie A. / Wells Philippe C. (1998): The Determinants of Venture Capital Funding: Evidence Across Countries, Working Paper, Social Science Research Network, Boston University

[27] Jenkinson, Tim / Ljungqvist, Alexander (1998): Going Public: The Theory and Evidence on How Companies Raise Equity Finance, Oxford

[28] Johnson, Simon (2000): Private Contracts and Corporate Governance Reform: Germany's Neuer Markt, Working Paper

[29] Kahneman, D. / Tversky, A. (1979): Prospect Theory: An Analysis of Decision under Risk, in: Econometrica, Vol. 47, pp. 263-291

[30] Kaserer, Christoph / Kraft, Marcus (2000): The Cost of Raising Capital and Issue Size Effects - The Case of Initial Public Offerings in Germany, Working Paper

[31] Kaserer, Christoph / Kempf, Volker (1995): Das Underpricing-Phänomen am deutschen Kapitalmarkt und seine Ursachen, in: ZBB 1/95, pp. 45-69

[32] Leopold, Günter / Frommann, Holger (1998): Eigenkapital für den Mittelstand: Venture Capital im In- und Ausland, Verlag C.H. Beck, München

[33] Lerner, Joshua (1995): Venture Capitalists and the Oversight of Private Firms, in: Journal of Finance, Vol. 50, No. 1, pp. 301-318

[34] Lessat, Vera / Hemer, Joachim / Eckerle, Tobias H. et al (1999): Beteiligungskapital und technologieorientierte Unternehmensgründung: Markt - Finanzierung - Rahmenbedingungen, Wiesbaden, Gabler Verlag

[35] Leuz, Christian (2000): IAS versus US GAAP: A "New Market" Based Comparision, Finance \& Accounting Working Paper, Frankfurt University, No. 48

[36] Lin, Timothy H. / Smith Richard L. (1998): Insider Reputation and Selling Decisions: The Unwinding of Venture Capital Investments during Equity IPOs, in: Journal of Corporate Finance, Vol. 4, pp. 241-263 
[37] Ljungqvist, Alexander P. / Jenkinson, Tim (2000): Has the Introduction of Bookbuilding Increased the Efficiency of International IPO?, CEPR Working Paper

[38] Ljungqvist, Alexander P. (1999): IPO Underpricing, Wealth Loss and the Curious Role of Venture Capitalists in the Creation of Public Companies, Working Paper

[39] Ljungqvist, Alexander P. (1997): Pricing Initial Public Offerings: Further Evidence from Germany, in: European Economic Review, Vol. 41, pp. 1309-1320

[40] Löffler, Gunter (2000): Zeichnungsrenditen am Neuen Markt: Gleichgewicht oder Ineffizienz? Working Paper, Frankfurt University

[41] Loughran, Tim / Ritter, Jay R. (1999): Why Don’t Issuer Get Upset About Leaving Money on the Table in IPOs? Working Paper

[42] Megginson, William L. / Weiss Kathleen A. (1991): Venture Capitalist Certification in Initial Public Offerings, in: Journal of Finance, Vol. 46, pp. 879-903

[43] Ochner, Kurt (2000): Theorie und Praxis der Greenshoe-Option, Börsenzeitung, No. 197, pp. 17

[44] Ritter, Jay R. (1984): The Hot Issue Market of 1980, in: Journal of Business, Vol. 57, pp. $215-240$

[45] Rock, Kevin (1986): Why New Issues are Underpriced, in: Journal of Financial Economics, Vol. 15, pp. 187-212

[46] Sahlman, William A. (1990): The Structure and Governance of Venture-Capital Organizations, in: Journal of Financial Economics, Vol. 27, pp. 473-521

[47] Smart, Scott B. / Zutter, Chad J. (2000): Control as a Motivation for Underpricing: A Comparison of Dual- and Single-Class IPOs, Working Paper

[48] Smith, Richard L. / Kiholm Smith, Janet (2000): Entrepreneurial Finance, John Wiley \& Sons, Inc.

[49] Stedler, Heinrich (1987): Venture Capital und geregelter Freiverkehr: Eine empirische Studie, Fritz Knapp Verlag, Frankfurt am Main

[50] Stehle, Richard / Erhardt, Olaf (1999): Renditen bei Börseneinführungen am deutschen Kapitalmarkt, ZfB, 69. Jg., pp. 1395-1422

[51] Theissen, Erik (1998): Der Neue Markt: Eine Bestandsaufnahme, in: Zeitschrift für Wirtschafts- und Sozialwissenschaften (ZWS), Vol. 118, pp. 623-652, Duncker \& Humblot, Berlin

[52] Tinic, Seha M. (1988): Anatomy of Initial Public Offerings on Common Stock, in: Journal of Finance, Vol. 43, No.4, pp. 789-822

[53] Uhlir, Helmut (1989): Der Gang an die Börse und das Underpricing-Phänomen, in: Zeitschrift für Bankrecht und Bankwirtschaft, No.1, pp. 2-16

[54] Wasserfallen, Walter / Wittleder, Christian (1994): Pricing Initial Public Offerings: Evidence from Germany, in: European Economic Review, Vol. 38, pp. 1505-1517

[55] Welch, Ivo (1989): Seasoned Offerings, Imitation Costs, and the Underpricing of Initial Public Offerings, in: Journal of Finance, Vol. 44, No. 2, pp. 421-449 
Internet Pages:

[56] Institut für Mittelstandsforschung (IfM)

http://www.ifm-bonn.org/dienste/gruendw.htm

[57] Neuer Markt

http://deutsche-boerse.com/nm/index_e.htm

[58] Deutsches Aktieninstitut

http://www.dai.de

[59] Federal Ministry of Economics and Technology

http:// www.bmwi.de 


\section{CFS Working Paper Series:}

\begin{tabular}{|c|c|c|}
\hline No. & Author(s) & Title \\
\hline $2000 / 10$ & $\begin{array}{l}\text { Antje Brunner } \\
\text { Jan Pieter Krahnen } \\
\text { Martin Weber }\end{array}$ & $\begin{array}{l}\text { Information Production in Credit Relationships: } \\
\text { On the Role of Internal Ratings in Commercial } \\
\text { Banking }\end{array}$ \\
\hline $2000 / 11$ & Roland Beck & $\begin{array}{l}\text { The Volatility of Capital Flows to Emerging } \\
\text { Markets and Financial Services Trade }\end{array}$ \\
\hline $2000 / 12$ & $\begin{array}{l}\text { Christian Schlag } \\
\text { Anja Wodrich }\end{array}$ & $\begin{array}{l}\text { Has There Always Been Underpricing and } \\
\text { Long-Run Underperformance? - } \\
\text { IPOs in Germany Before World War I }\end{array}$ \\
\hline $2000 / 13$ & Roland Eisen & $\begin{array}{l}\text { (Partial) Privatization Social Security: } \\
\text { The Chilean Model - A Lesson to Follow? }\end{array}$ \\
\hline $2001 / 01$ & Stefanie Franzke & $\begin{array}{l}\text { Underpricing of Venture-Backed and Non } \\
\text { Venture-Backed IPOs: Germany's Neuer Markt }\end{array}$ \\
\hline $2001 / 02$ & Roland Beck & $\begin{array}{l}\text { Do Country Fundamentals Explain Emerging } \\
\text { Market Bond Spreads? }\end{array}$ \\
\hline $2001 / 03$ & $\begin{array}{l}\text { Markus Kern } \\
\text { Bernd Rudolph }\end{array}$ & $\begin{array}{l}\text { Comparative Analysis of Alternative Credit } \\
\text { Risk Models - an Application on German } \\
\text { Middle Market Loan Portfolios - }\end{array}$ \\
\hline $2001 / 04$ & $\begin{array}{l}\text { Antje Brunner } \\
\text { Jan Pieter Krahnen }\end{array}$ & $\begin{array}{l}\text { Corporate Debt Restructuring: Evidence on } \\
\text { Lender Coordination in Financial Distress }\end{array}$ \\
\hline $2001 / 05$ & $\begin{array}{l}\text { Ralf Ewert } \\
\text { Andrea Szczesny }\end{array}$ & $\begin{array}{l}\text { Countdown for the New Basle Capital Accord. } \\
\text { Are German Banks ready for the Internal } \\
\text { Ratings-Based Approach? }\end{array}$ \\
\hline $2001 / 06$ & Bernd Kaltenhäuser & $\begin{array}{l}\text { Explaining the Dollar-Euro Rate: Do Stock } \\
\text { Market Returns Matter? }\end{array}$ \\
\hline
\end{tabular}

Copies of working papers are available at the Center for Financial Studies or can be downloaded (http://www.ifk-cfs.de). 